\title{
Advanced Turbine Systems Program Conceptual Design and Product Development Task 5 -- Market Study of the Gas Fired ATS
}

\section{Topical Report}

May 1995

Work Performed Under Contract No.: DE-AC21-93MC30246

For

U.S. Department of Energy

Office of Fossil Energy

Morgantown Energy Technology Center

Morgantown, West Virginia

By

Solar Turbines Incorporated

San Diego, California 


\section{DISCLAIMER}

This report was prepared as an account of work sponsored by an agency of the United States Government. Neither the United States Government nor any agency thereof, nor any of their employees, makes any warranty, express or implied, or assumes any legal liability or responsibility for the accuracy, completeness, or usefulness of any information, apparatus, product, or process disclosed, or represents that its use would not infringe privately owned rights. Reference herein to any specific commercial product, process, or service by trade name, trademark, manufacturer, or otherwise does not necessarily constitute or imply its endorsement, recommendation, or favoring by the United States Government or any agency thereof. The views and opinions of authors expressed herein do not necessarily state or reflect those of the United States Government or any agency thereof.

This report has been reproduced directly from the best available copy.

Available to DOE and DOE contractors from the Office of Scientific and Technical Information, 175 Oak Ridge Turnpike, Oak Ridge, TN 37831; prices available at (615) 576-8401.

Available to the public from the National Technical Information Service, U.S. Department of Commerce, 5285 Port Royal Road, Springfield, VA 22161; phone orders accepted at (703) 487-4650. 


\title{
Advanced Turbine Systems Program Conceptual Design and Product Development Task 5 -- Market Study of the Gas Fired ATS
}

\author{
Topical Report
}

Work Performed Under Contract No.: DE-AC21-93MC30246

For

U.S. Department of Energy

Office of Fossil Energy

Morgantown Energy Technology Center

P.O. Box 880

Morgantown, West Virginia 26507-0880

By

Solar Turbines Incorporated

2200 Pacific Highway

San Diego, California 92138

May 1995 


\section{CONTENTS}

Section

Page

1

INTRODUCTION

1.1 Background 2

2

DEFINITION OF ATS' MARKET APPLICATION

3.1 Competing Technologies and System Configurations

3.2 Characterization per Application

4.1 Competitive Advantage of Selected ATS

4.2 Comparison of Technical, Economic, Environmental Features

5.1 Macro-Characterizations Per Primary Market

5.2 Micro-Characterizations Per Primary Market Segment

APPENDIX A - Description/Definition of Solar's Advanced Turbine Systems

APPENDIX B - RDC Report

B-1

APPENDIX C - Onsite Energy Report

C-1 


\section{FIGURES}

Figure

Page

1

QFD Chart

3

\section{TABLES}

Table

Page

1

Pugh Chart

ATS Demonstrates Flexible Operation in Cogeneration

Competing Systems for Electrical Generation

Comparison of ATS With Fuel Cells

U.S. Primary Metal Industry Energy Use, 1988 


\subsection{INTRODUCTION}

Solar Turbines Incorporated (Solar), in partnership with the Department of Energy, will develop a family of advanced gas turbine-based power systems (ATS) for widespread commercialization within the domestic and international industrial marketplace, and to the rapidly changing electric power generation industry. The objective of the jointly-funded Program is to introduce an ATS with high efficiency, and markedly reduced emissions levels, in high numbers as rapidly as possible following introduction.

This Topical Report is submitted in response to the requirements outlined in Task 5 of the Department of Energy METC Contract on Advanced Combustion Systems, Contract No. DE AC21-93MC30246 (Contract), for a Market Study of the Gas Fired Advanced Turbine System. It presents a market study for the ATS proposed by Solar, and will examine both the economic and siting constraints of the ATS compared with competing systems in the various candidate markets.

Also contained within this report is an examination and analysis of Solar's ATS and its ability to compete in future utility and industrial markets, as well as factors affecting the marketability of the ATS. This includes system configuration and performance rating, system cost, cost of electricity, fuel flexibility and expected pricing. Particular attention will be paid to environmental impact considerations, as well as expected emissions levels for the ATS.

As defined by the DOE, the ATS will reduce the cost of power by at least ten percent below today's generation systems, and will offer a level of reliability, availability, maintainability and durability that customers of Solar's dependable equipment have come to expect. In addition, the ATS will operate at thermal efficiencies at least 15 percent higher than 1991 products, and with emissions not exceeding 9 ppmv NOx, and 20 ppmv CO and UHC.

Driven by an optimized recuperated gas turbine engine, the ATS system will deliver thermal efficiencies of up to 43.2 percent ( 45.5 percent ISO engine). This advanced turbine system will be flexible enough to meet the different operational requirements of a wide variety of commercial/ industrial market applications.

Solar's ATS will meet the technical, commercialization and environmental objectives set out by the DOE. The system responds to specifically identified customer buying criteria in order to ensure rapid adoption in large quantities. Advanced technologies developed for the ATS program will spin off to benefit current Solar products, and will be deployed into the large pool of existing equipment through retrofit and upgrades to improve the performance of existing equipment already in the field, multiplying the environmental and performance benefits. 


\subsection{BACKGROUND}

In the course of laying out the program for the Phase II Market Study Report, Solar's ATS Program Management selected two separate market researchers to conduct independent studies of the potential ATS Markets. One was to conduct an in-depth market analysis following an outline structured from the ATS Statement of Work under Contract with Solar (Part III. Section J, Attachment A, Scope of Work). The other was asked to provide an analysis using the same outline as a guide, but to approach the market study with greater latitude in scope and format.

Resource Decision Consultants (RDC) was selected to support Solar's ATS program and the market study as the principal market research firm. RDC was submitted as a selected contractor to the Dept. of Energy, and was approved for placement on the program. Appendix A contains elements of RDC's report, including a section describing RDC, and a brief biographical detail on Dr. Jim Williams.

Onsite Energy Corporation (Onsite), was selected to conduct market research from a different background and perspective. Onsite's principal investigator, Mr. Keith Davidson, has an extensive background in the natural gas industry, and has focused on commercialization strategies for emerging gas markets. Onsite was submitted as a selected contractor for the Market Study, and was approved by the DOE. Appendix B contains elements of the Onsite report, including a section on the company and Mr. Davidson, the principal investigator.

In the early months of Phase II, Solar conceptualized a system configuration based on an intercooled, recuperated turbine engine. While this configuration was chosen to begin the effort of analyzing the ability of the system to meet the technical goals of the DOE's Program, Solar instructed its marketing staff to provide feedback on the acceptance in the market place of such a size and cycle.

The researchers, in the course of their study, contacted many potential customers. Solar, drawing on 30 plus years of commercialization, identified drawbacks to the cycle and size initially selected. With the use of the Quality Function Deployment (QFD) analysis methodology (Figure 1), as well as application of the Pugh Chart (Table 1), Solar developed a set of matrices that took into consideration the DOE's Program goals, the customer's buying criteria, and Solar corporate objectives, to alter the selected system to more closely align with the market requirements. Ultimately, the optimized recuperated cycle was selected as the ATS most closely aligning with the market requirements without compromising the ATS Program goals.

The Task 6 Topical Report - System Definition and Analysis, provides an in-depth description of the selected ATS configuration. Appendix A of this report contains a summary description and definition of Solar's ATS. 


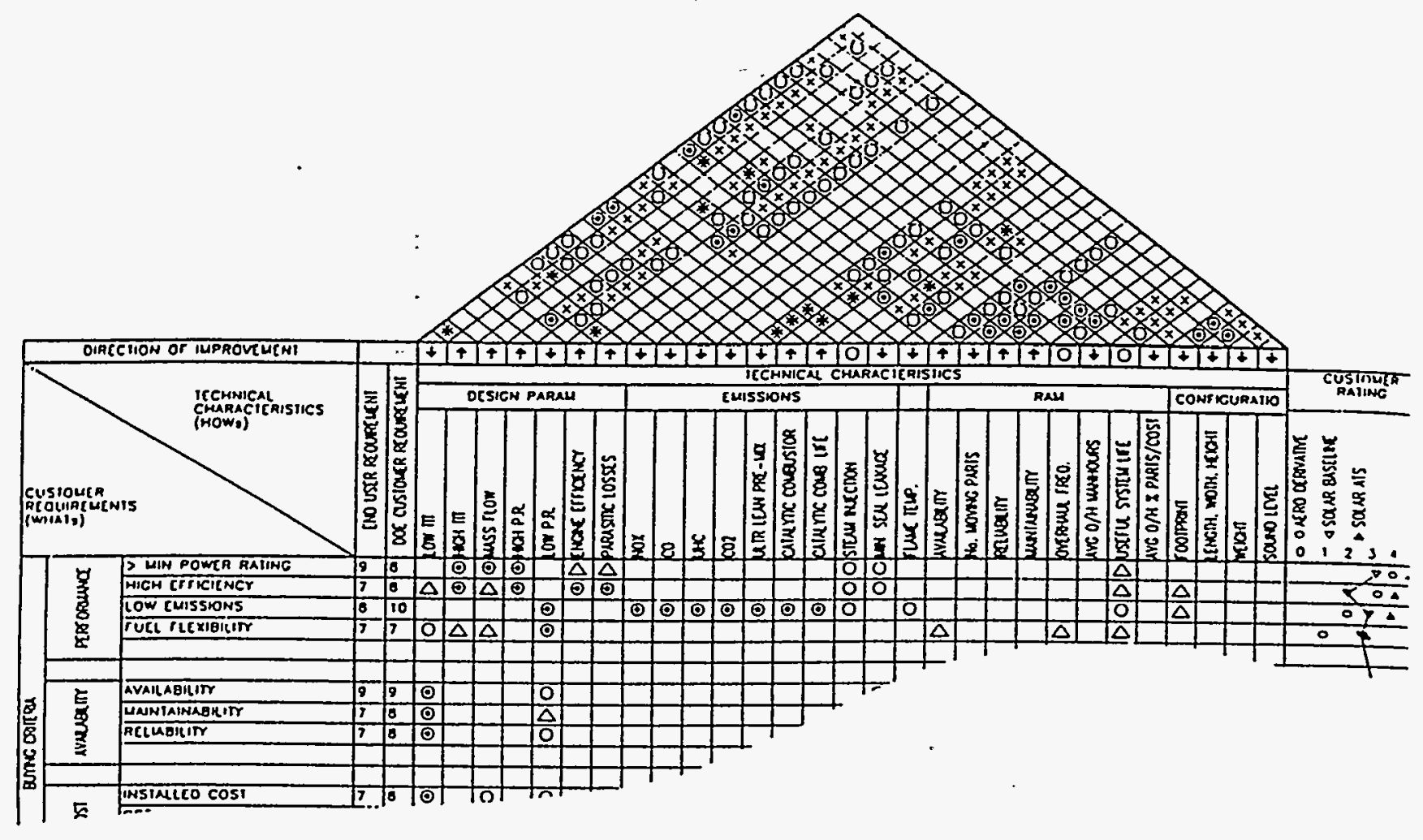

Figure 1. QFD Chart

Table 1. Pugh Chart

\begin{tabular}{|c|c|c|c|c|c|c|c|c|c|}
\hline CAITERIA & 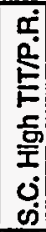 & 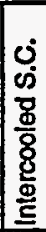 & 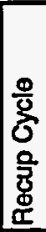 & $\begin{array}{l}\frac{0}{0} \\
\frac{0}{0} \\
\frac{\sigma}{0} \\
\underline{0}\end{array}$ & 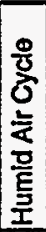 & 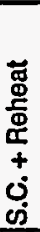 & 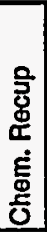 & 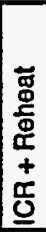 & 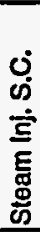 \\
\hline Low Emission & - & + & + & + & + & 0 & + & + & + \\
\hline High Efficiency & + & 0 & + & + & + & + & + & + & + \\
\hline Low Lffecycle Cost & + & + & + & + & 0 & 0 & 0 & 0 & $\mathbf{0}$ \\
\hline Low First Cost & - & 0 & 0 & - & - & - & - & - & - \\
\hline High Power Rating & + & + & 0 & + & + & 0 & 0 & + & + \\
\hline Low Risk - Schedule & - & 0 & 0 & - & - & $\mathbf{0}$ & - & - & $\mathbf{0}$ \\
\hline Low Risk - Technology & - & 0 & 0 & 0 & - & 0 & - & - & 0 \\
\hline Low Risk Cost & - & 0 & 0 & - & - & 0 & - & - & 0 \\
\hline High RAMD & - & 0 & 0 & - & - & - & - & - & - \\
\hline Spinoff Technology & + & 0 & + & + & - & 0 & + & + & 0 \\
\hline Fuel Flexibility & - & - & + & - & - & + & + & - & 0 \\
\hline Strateglc Fit & + & - & + & + & + & 0 & + & + & 0 \\
\hline Tech. Integration & 0 & - & 0 & - & - & 0 & - & - & 0 \\
\hline Cust. Acceptance & - & - & 0 & - & - & 0 & - & - & \\
\hline Total +'s & 5 & 3 & 6 & 6 & $\overline{4}$ & $\overline{2}$ & 5 & 5 & 3 \\
\hline Total -'6 & 8 & 4 & 0 & 7 & 9 & 2 & 7 & 8 & 2 \\
\hline
\end{tabular}

Note: Baseline Is 1994 S.O.A. Industrial Gas Turbine System

RERISTM 


\subsection{DEFINITION OF ATS MARKET APPLICATION}

Electrical Power Generation. The ATS can be used as an electrical power generation system to meet the requirements of electric utility customers. The market is generally defined by the types of electrical generators, such as: investor-owned utilities, municipal utilities, rural electric cooperatives, and independent power producers.

The ATS can be applied in both traditional (baseload and cycling) setting, and the most recent development, distributed/dispersed generation applications. As electricity peak demand continues to grow at or above the nation's Gross Domestic Product (GDP) through the remainder of the decade and beyond, this trend will create major opportunities for the ATS due to its strategic application as well as its high efficiency, low capital cost, short installation lead time and compliant environmental emissions.

Privately-owned regulated utilities. supply the largest portion of the electricity-consuming market. There are currently 260 privately-owned utilities, whose sales to 86 million customers account for roughly 76 percent of the total U.S. electricity demand, or $2.1 \mathrm{GWh}$ in 1992. Publicly-owned systems, including 2,024 state and municipal utilities and 10 federal power agencies serving 15.6 million customers, accounted for 16 percent of U.S. utility electricity sales in 1992, selling $445 \mathrm{GWh}$. A total of 941 local.cooperatives provided 207 thousand GWh, or 7.5 percent of the total U.S. demand for electricity, to their 12 million customer/owners.

Although independent power producers generate nearly 5 percent of the electricity in the U.S., this power is almost exclusively sold to electric utilities. As a result of the Public Utilities Regulatory Act of 1978 and implementation of FERC and state regulations, electric utilities may (and sometimes are required to) purchase electricity from non-utility generators (NUGs). As a result of the 1992 Energy Policy Act, NUGs and electric wholesale generators (EWGs), can compete with traditional utility electricity generation. Each segment of this realigning U.S. electric power industry - electric utilities, NUGs and EWGs - are candidates for the ATS in most, if not all, applications.

The electrical power industry is undergoing a fundamental change in moving toward deregulated generation and competitive market for power supply that will successfully challenge the traditional view of an integrated (generation-transmission-distribution) utility that operates as a legally franchised, regulated monopoly. NUGs have become an increasingly attractive economic alternative to large central station utility-owned power plants. With wholesale and retail wheeling and more utility size "merchant plants", utilities are afforded the opportunity to purchase power at or below their cost. The days of "bigger is better," the primary justification of a regulated monopoly, are long over. More recently, the Clean Air Act Amendments of 1990 and the Energy Policy Act of 1992 have offered additional changes that will promote the economic competition of NUGs. As a result of these facilitating regulations, NUGS have increased tremendously in the past 15 years, with an outlook of continued growth for the future. 
These legislative developments, along with changes in market forces have opened a viable commercial market opportunity for smaller-scale, gas turbine systems capable of providing efficient, reliable and relatively inexpensive electrical power.

Cogeneration, comprising a large percentage of the existing NUG power today, offers many benefits when compared to central power plants. These benefits include an increased efficiency over central power plants, the value of the steam to the host site, the ability to meet peak load requirements, reduced pollution, distributed power benefits and increased reliability.

In sum, the electric power generation markets represent the largest potential markets for the ATS due to the competitive response underway to deregulation and the onset of distributed power generation supplementing larger, more centralized power sources.

Oil and natural gas production, transmission and storage. The largest existing market for the ATS includes Solar's traditional gas and oil pipeline and storage industries, including production and processing as well as transmission and storage companies. This industrial segment will be growing in response to increasing worldwide demands for energy and fuel. Hence, these oil and gas sectors, which depend extensively on pumping equipment and systems, represent clear opportunities for the ATS with a capacity between roughly 1,000 and $40,000 \mathrm{hp}$. With a high-efficiency level of around 43 percent, a low capital and maintenance cost, coupled with compliant emissions performance, the ATS is a very competitive option for the oil and natural gas industries.

Deregulation is occurring much more slowly in the gas production segment. However, as a result of the pipeline deregulation, local gas utilities and large users increasingly deal directly with gas producers to obtain their supplies. Deregulation has also placed pressure on increased operating efficiency and cost reduction. Reducing maintenance and energy costs, and increasing the use of reduced manning and remote operations will become important management and operation goals within the gas industry.

The increasing difficulty of environmental compliance is a key issue facing the pipeline industry. Regulations regarding exhaust emissions (primarily NOx) and noise are making environmental compliance a major hurdle, which has essentially become a go/no go issue in driver/compressor purchasing decisions. There is some sentiment within the industry that electric drives may be the only practical solution to some siting problems.

Another major change affecting the natural gas industry is the increased stringency of air emissions regulations. Notably the 1990 Clean Air Act Amendment (CAA) has improved the perceived desirability of natural gas as a fuel choice. It also has imposed control requirements on compressor station operators that represent major hurdles and cost implications. The primary objective of the CAA legislation with regard to the pipeline industry was to impose Lowest Achievable Emission Rate (LAER) for compressor station emissions on a case-by-case basis. 
The primary application opportunity in the oil and gas industry for Solar's ATS lies within natural gas compression and oil transmission pumping. Presently, there are over 7,700 compressors currently in use in natural gas compression applications. Approximately 85 percent of natural gas compressors currently installed utilize reciprocating engine drivers. Based on an industry survey conducted in 1993 by SRI, major purchasing factors, in order of importance are: capital cost, environmental performance, operating costs, efficiency and siting. Of these, capital cost and environmental were significantly more important than the other criteria. Other potential market opportunities include manufacturing operations, large commercial and multifamily residential applications, as well as water transportation and treatment industries.

Industrial Prime Movers. The industrial sector accounts for more than 36 percent of total end-use energy consumption. Process heat accounts for the largest share of energy consumption in industry overall, and mechanical shaft drive represents another large use of energy in many industries. This sector represents a significant opportunity for the ATS.

In particular, the ATS is well suited to industries with requirements for steam. If an industry requires high process steams, the ATS provides the same air flow for high pressure steam and can be turned down without compromise to its electrical efficiency.

The ATS can be used for industrial manufacturing power generation to meet on-site plant requirements, including mechanical shaft power for compressors, and pumps in petrochemical and other process energy intensive applications, and in electric/thermal congeneration to serve a portion of on-site electric and process steam demands in manufacturing plants depending extensively a on low-cost, reliable electricity supply.

In cogeneration applications, the recuperated ATS is best suited for industries with low thermal requirements because of its very high electrical efficiency. Since its combustion gases are relatively low in energy, the ATS is best suited to industries with a high ratio of electric energy needs to thermal energy needs ( $E / T$ ratio).

While the recuperated ATS as a stand alone is best suited for industries with high electricity requirements relative to requirements for steam or thermal energy, ATS with supplemental duct firing can be an attractive option. Furthermore, simple cycle systems which incorporate ATS technologies will likewise increase the range of operational flexibility afforded by the proposed Solar family of ATS products.

Other potential markets include manufacturing operations, large commercial and multifamily residential applications, as well as water transport and treatment industries.

Marine Propulsion. A market segment that has recently emerged with a potential for the ATS-size power system is high speed craft propulsion. While the shipping industry overall has not grown substantially in recent years, the high speed segment has demonstrated strong vitality and growth. 
Prospects for future growth remain strong as the increasing speed and ride quality of today's fast ferries make them very competitive with other forms of surface transportation and short haul airlines. The growth of passenger vessels has been especially strong in developing countries in the Asia-Pacific Region. Larger, high speed vehicle and passenger

ferries have shown strong growth in northern Europe, the British Isles and the Mediterranean.

The passenger carry vessels currently have a total installed power of 8-10 MW and the larger car and passenger vessels have a total installed power of 20-40 MW. With these power plants typically consisting of two separate engine rooms, there is a good fit between the needs of these vessels and 5 and $15 \mathrm{MW}$ marine gas turbines.

As speeds of marine transportation systems or "fast ferries" have continued to increase, the power-to-rate ratio has also become a key product feature. The gas turbine's lightweight and compact size are highly desirable, however they are competing against reciprocating engines in the 39-44 percent thermal efficiency range. For commercial operators, fuel is the largest operating expense. The higher thermal efficiency of an Advanced Turbine System will make it a very competitive propulsion engine for future high speed marine transportation systems.

However, these application opportunities are currently exclusively overseas, and are designed to use liquid fuels, and therefore, are expected to be a specialized niche market until at least the end of the century. 


\subsection{CHARACTERIZATION OF COMPETING SYSTEMS}

Within the utility, industrial, commercial/residential, mechanical drive and transportation markets, the industrial ATS will compete with several technologies. The primary competition for the ATS includes the following: simple cycle gas turbines, combined cycle gas turbines, cogeneration, reciprocating engines, and fuel cells.

\subsection{COMPETING TECHNOLOGIES AND SYSTEM CONFIGURATIONS}

The simple cycle gas turbine is the primary combustion turbine the ATS would replace. They range in size from $500 \mathrm{~kW}$ to $200 \mathrm{MW}$, although the industrial size gas turbine is usually 1 to $20 \mathrm{MW}$. They have small footprints resulting in very good power densities that range from 5 to $300 \mathrm{~kW} / \mathrm{sq}$.ft. The existing simple cycle industrial turbine have a thermal efficiency of 32-36 percent at the shaft.

The ATS will have modestly higher capital cost than a simple cycle, but that will be outweighed in most applications by the increased performance. The simple cycle turbine presently is used in utility peaking, industrial cogeneration, mechanical drive, and high speed marine applications. The ATS will be very attractive in all of these applications, and would be best used as an intermediate or base load distributed generator for the utility applications.

Combined cycle combustion turbine power plants range in size from $4 \mathrm{MW}$ to $1,000 \mathrm{MW}$ and have efficiencies of 40 to 48 percent. Combined cycle gas turbines are projected to be the most attractive generator for utility baseload requirement capacity in the near term. They would not presently compete in the utility distributed market unless they also served as an industrial or cogeneration application. Their size range is high for a typical industrial gas turbine application. The industrial ATS will probably compete with combined cycle systems for opportunities in peaking generation.

Many cogeneration systems are composed of reciprocating engines, especially in applications below $5 \mathrm{MW}$. Reciprocating engines range in size up to $10 \mathrm{MW}$, although they rarely exceed 1 to $4 \mathrm{MW}$. With electrical efficiencies of 20 to 30 percent, and with the thermal energy usage of a cogeneration system, reciprocating engines can attain overall energy efficiencies of 75 to 85 percent. In $5 \mathrm{MW}$ and up size ranges, simple cycle gas turbines are being employed for cogeneration applications. Gas turbines are usually used when high temperature steam is required in the cogeneration applications. It should be noted that while the overall efficiency is relatively good, the waste heat needs to be collected from two sources, the jacket water and the exhaust. The complexity of capturing that heat is more so than a gas turbine with only the exhaust heat to capture.

Fuel cells have drawbacks to their placement in applications and markets on which the ATS is focused. Footprint, or power density is a major consideration above 2-3 MWe. Initial first cost as well as operation and maintenance costs adversely affect the economics 
of their placement. As a result, the fuel cell will not be much of a competitive threat to the ATS.

Early pipeline compressors were of an integral design in which the reciprocating compressor shared a common crankshaft and crank case with that of the reciprocating engine driver. These mostly used 2-stroke, spark-ignited engines designed to run at a constant output. Sizes ranged from a few hundred hp to nearly $15,000 \mathrm{hp}$, with a majority of the early units falling in the 500 to $2,000 \mathrm{hp}$ size range.

In the early 70's, the design trends resulted in engine/compressor sets with separable components (separate engine and compressor, for instance). Most pipeline units drive a separate reciprocating compressor, and most installations were based on medium speed diesel engines, usually converted to use natural gas.

In general, older reciprocating engines are gradually being retired or retrofitted. Sales of reciprocating engines continue to decline. R\&D efforts to improve this technology are concentrated primarily on improving emissions performance.

Nuclear power does not pose much of a market threat to the ATS, due primarily to negative public reaction, the time and cost evolved in placing a plant on-line, and due to several large generating plants due to retire in the next five to ten years.

While nuclear plants produce $21.75 \%$ of all electricity generated by utilities, public opinion remains against new nuclear construction. However research continues. Generally, there are expected to be no new plants constructed. In fact, economics and sometimes regulatory considerations have retired some units prior to the expiration of their operating licenses.

\subsection{CHARACTERIZATION PER APPLICATION}

One demand forecast published in the 1992 Electricity Report (ER 92) by the California Energy Commission predicted that between 2000 and 2010, the State of California will experience a growth in its peak summer demand increasing from 59 Gigawatt (GW) in 2000 to $70 \mathrm{GW}$ in 2010, averaging approximately $1.1 \mathrm{GW}$ per year.

In addition to predicting the growth in demand, the ER92 contains a resource expansion analysis that develops a list of recommended capacity expansion projects to meet the growing electricity demand. ER92's forecasted resource additions indicates $4 \mathrm{GW}$ of natural gas fired generation capacity will be installed between 1996 and 2003, corresponding to an average of $600 \mathrm{MW}$ per year.

\section{ATS Cogeneration Market Potential.}

Cogeneration is used by many industries, typically in the form of steam, for various manufacturing processes. Most industrial plants produce their steam or thermal energy requirements in a boiler and separately purchase their electric power from the electric

utility grid. An industrial facility using cogeneration produces both steam and electrical 
energy in the same process using the same primary energy input. Because the same energy input is used twice, cogeneration is inherently more efficient than the separate production of both steam and power.

By creating a value for recovered heat, small generators can overcome the inherent cost and shaft efficiency disadvantage relative to large control station combined cycle plants. Although historical trends have recorded a diminishing market for retail cogeneration, a number of emerging factors, most notably industrial sited distribution generation, could lead to a resurgence in retail cogeneration in the late 1990's.

A wide range of outputs for cogeneration users will be available, as shown in Table 2

Table 2. ATS Demonstrates Flexible Operation in Cogeneration

\begin{tabular}{|l|c|c|c|c|c|}
\hline Configuration & \multirow{2}{*}{$\begin{array}{c}\text { Power } \\
\text { (normalized } \\
\text { to 1.0) }\end{array}$} & $\begin{array}{c}\text { Steam } \\
\text { (pph) }\end{array}$ & $\begin{array}{c}\text { Peak Fuel Flow } \\
\text { (normalized to } \\
\text { 1.0 MMBtu/h) }\end{array}$ & \multicolumn{2}{|c|}{ Efficiency } \\
\cline { 5 - 7 } & 1.0 & 0 & 1.0 & 43.2 & 43.2 \\
Basic ATS & 0.98 & As required & 1.0 & 42.1 & 78.1 \\
ATS + HRSG* & 1.71 to 0.97 & As required & 2.83 & 26 & 91 \\
ATS + BPST** & \multicolumn{4}{|l}{}
\end{tabular}

* Heat Recovery Steam Generator

${ }^{\star \star}$ Back Pressure Steam Turbine

Expanded Market Opportunity. Energy efficiency will become increasingly under watch in the commercial, large residential building complexed multi-building commercial facilities with central physical plants represent potential opportunities for cogeneration and for prime mover driven cooling equipment. Steam used for recovered exhaust heat includes space heating domestic hot water, and absorption cooling. According to the EIA, buildings on multibuilding facility sites accounted for 50 percent (2.9 quadrillion BTU) of the energy consumed in all commercial buildings in 1989. 


\subsection{COMPETITIVE ANALYSIS}

\subsection{COMPETITIVE ADVANTAGE OF SELECTED ATS}

The ATS has many attributes such as low emissions, high availability and high efficiency, which will make it equal, if not superior to most current and advanced gas-fired power systems available in the market after the year 2000.

Low emissions is growing in importance to customers making equipment purchase decisions. Availability has consistently been--and will remain for the foreseeable future-the paramount technical buying criterion because equipment downtime has the greatest adverse cost impact. Efficiency affects the cost of power through the cost of fuel. Fuel cost is the largest component of cost for any system running a high duty cycle.

Solar employs Quality Function Deployment (QFD), a rigorous process of matching customer need to technical capabilities to ensure customer buying criteria translates directly into features of their product. This assures a high incidence of meeting or exceeding customer expectations.

ATS is most cost competitive in electric power distributed generation, peaking and intermediate applications, and in mechanical drive for the manufacturing and the natural gas and oil production and transmission industries. This is principally attributable to the fact that competitors with equal and greater efficiencies are also more expensive to purchase and maintain.

\subsection{COMPARISON OF TECHNICAL, ECONOMIC, ENVIRONMENTAL FEATURES}

Table 3 compares some competing systems for electrical generation on four important performance factors. Competing systems for distributed power range from storage batteries to fuel cells sited locally. ATS will be competitive in these markets, especially when transmission and distribution costs are considered.

The fuel cell is frequently cited as a candidate for distributed power. Table 4 compares the fuel cell with the ATS in 12 important areas. ATS holds a clear advantage in nearly all of these areas.

The ATS offers an environmentally friendly installation. There are significant advantages for a distributed power unit located in residential or commercial areas. Without additional silencing, the ATS will be quiet ( $85 \mathrm{dba}$ at $3 \mathrm{~m}$ for the recuperated version, without additional silencers), have lower emissions (8 ppmv NOx, $10 \mathrm{ppmv}$ CO and $10 \mathrm{ppmv}$ UHC) than local traffic. ATS will also be safe (contractors digging into local power and gas lines present a greater source of problems). 
Table 3. Competing Systems for Electrical Generation'

\begin{tabular}{|l|c|c|c|c|}
\hline System & Avaliabilty (\%) & NOx Emissions (ppm) & Installed Cost (\$/kW) & Thermal Emclency (\%) \\
\hline ATS & 98 & 5 & 650 & 43.2 \\
\hline ATS + HRSG & 98 & 5 & $1000-1100$ & up to $74 \%$ \\
\hline Simple Cycles Aeroderivative & 92 & 25 & 718 & 39 \\
\hline Simple Cycle GT Heavy Duty & 92 & 25 & 550 & 28.7 \\
\hline GT-Combined Cycle & 92 & 9 & 700 & 58 \\
\hline $\begin{array}{l}\text { GT-Chem Recup/Rebeat/Inter- } \\
\text { cooled }\end{array}$ & 90 & $<5$ & $850-1000$ & 57.2 \\
\hline Storage Battery (5 hour) & 91 & $0 *$ & 804 & 86.2 \\
\hline Gas Boiler/Steam Turbine & 95 & 25 & 600 & 35 \\
\hline Conventional Gas Turbine & 95 & 25 & 650 & 34.5 \\
\hline Phosphoric Acid Fuel Cell & 91.6 & Trace & 3000 & 41.1 \\
\hline Molten Carbonate Fuel Cell & 97 & Trace & 3000 & 52.9 \\
\hline Reciprocating Gas Engines & 91 & 42 & 600 & 39 \\
\hline Steam Injected Gas Turbine & 92 & 5 & $850-1000$ & \\
\hline
\end{tabular}

1 Some data from EPRI Technical Assessment Guide.

${ }^{2}$ Does not include all emissions at other sources.

Table 4. Comparison of ATS With Fuel Cells

\begin{tabular}{|l|l|l|}
\hline \multicolumn{1}{|c|}{ Factor } & \multicolumn{1}{|c|}{ Fuel Cells } & \multicolumn{1}{c|}{ ATS } \\
\hline Emissions (Nox) & $1-4 \mathrm{~g} / \mathrm{GJ}$ & 5 ppmv NOx (equal to $7 \mathrm{~g} / \mathrm{GJ})$ \\
\hline Electrical Efficiency & $40-50 \%$ (low voltage D.C.) & $42.8 \%$ (high voltage AC) \\
\hline Overall Thermal Efficiency & $80 \%\left(82^{\circ} \mathrm{C}\right.$ hot water) & $91 \%(103 \mathrm{MPa}$ steam) \\
\hline Cost (1992 Dollars) & $\sim \$ 3000 / \mathrm{kWe}$ & $\$ 650 / \mathrm{kWe}$ \\
\hline Footprint & $0.23 \mathrm{~m}^{2} / \mathrm{kWe}$ & $0.042 \mathrm{~m}^{2} / \mathrm{kWe}$ \\
\hline Noise & Low (mainly reformer) & Low (Recuperator) \\
\hline Load Following & $\begin{array}{l}\text { Moderately good (limited to slow rates } \\
\text { of load change) }\end{array}$ & Excellent \\
\hline Fuel Flexibility & Limited (H $\mathrm{H}_{2}$ or reformed CH $)$ & Good \\
\hline Scale-Up/Technologyf Transfer & Thermal management difficult & No problems \\
\hline Reliability/Availability/Maintainability & Poor, under evaluation & Good \\
\hline Operating Costs & $\begin{array}{l}\text { Round the clock operation of reformer } \\
\text { system currently required }\end{array}$ & Can be operated without personnel \\
\hline Start-Up & Typically 8 hours & Less than 5 minutes \\
\hline
\end{tabular}




\subsection{DEFINITION OF PRIMARY MARKETS}

Solar analyzes primary and secondary users of industrial gas turbines in terms of "growth" and "new" markets. In growth markets, the industrial gas turbine is already accepted. New markets are those in which the industrial gas turbine is not heavily used, but which will be opened as a result of commercializing the ATS. The new markets are primarily in subsectors of the utility industry and especially in the application of distributed power.

Primary users in both markets are industrial, oil and gas, commercial/institutional and utility. Secondary users are residential and transportation.

Market Segments. The industrial ATS will be an attractive generation operation for the following market areas:

- Utility

- $\quad$ Oil and Gas

- Industrial

- Commercial/Residential

Utility Market. Defined as any power producer whose primary interest is in selling power to others. Utilities are undergoing significant changes in structure and the way they perform their business. It is clear that large, central station power plants will continue to dominate the majority of U.S. generation capacity. However, it is also clear that distributed generation will play a more significant role in utility power generation.

Utilities generally separate generation. capacity into three categories: Baseload, Intermediate and Peaking. Base load units operate almost continuously and are usually the utility's least expensive and largest central stations. These do not operate efficiently at part load. The peaking plants have low annual operating hours, short start up times, low capital cost, but high operating cost. The characteristics of intermediate generators fit somewhere between the other two load types. ATS will be a good candidate for the traditional utility intermediate load market, and will also find significant application in peaking and base load.

Oil \& Gas Production \& Transmission. The Oil \& Gas industry includes production and transmission of oil and gas, both on and off shore. Other major applications include gas compression and transmission related to both production and pipeline industry segments.

Natural Gas Industry. Major changes in the U.S. natural gas pipeline industry over the past ten years, including deregulation, have significantly changed the course of the selection and construction of new pipeline technologies, and has opened significant opportunities for the ATS. Until recently, the industry was tightly regulated, and costs were simply passed along to customers. Efficiency was relatively unimportant. Deregulation of the industry dramatically changed this scenario. A series of orders issued by The Federal Energy Regulatory Commission (FERC) effectively converted pipeline 
companies into gas transportation competitors, focusing these companies' attention on operating efficiencies and cost reductions. Reducing maintenance and energy costs, and increasingly tuming to remote, unmanned operations, will gain importance in considering equipment replacements within this newly-directed industry.

The primary natural gas industry ATS application lies within natural gas compression and oil transmission pumping. Over 7,700 compressors are currently in use in natural gas compression applications, many of which are still in service after 40 years of operation, due to the extreme conservatism in design philosophy that drove early driver/compressor designs.

The gas industry faces a need to repower existing compressor stations as efficiency improvements gain increasing importance as this industry looks to accommodate increased pumping loads, to improve the reliability of existing units, and to lower the accelerating cost of maintenance for existing equipment.

According to discussions with engineering and vendor firms, it is estimated that the potential market for new compressor drivers purchased/installed within the U.S. could range between 50 and 100 annually, as the industry acts to repower existing compressor stations to gain efficiency improvements to remain competitive.

Oil Industry. The U.S. petroleum pipeline network encompasses over 204,000 miles of transmission pipeline, and over 108,000 miles of crude oil pipelines carrying domestic and crude oil from producing fields and ports to refineries. In addition, there are over 72,000 miles of refined-product lines moving gasoline and other products to market, and over 23,000 miles of LPG lines transporting commodities such as propane and ethane. There have been shifts within the industry, and crude oil pipeline mileage has declined while product pipeline has increased.

There appears to be enough domestic crude oil pipeline capacity for the next 10 to 20 years, and there are no major logistical problems anticipated. Some additions may be made in order to remove bottlenecks and improve flow as supply and demand changes occur.

The primary factors affecting the selection of driver technology appear to be the same for both the oil and natural gas industry. Major purchase factors affecting purchase decisions include: capital cost, environmental performance, operating costs, efficiency and siting. Of these factors, the major issues are capital cost and environmental performance.

The U.S. pipeline industry is significantly affected by the issue of environmental compliance. Regulations regarding exhaust emissions (primarily NOx) and noise are making environmental compliance a major problem for the industry, since current technology solutions are limited.

Pipeline companies and local distribution companies are expected to become more involved in electric power generation as the electric industry becomes increasingly more competitive and it becomes easier for new competitors to enter the market. This trend will 
also feel the effects of attempts to further reduce operating costs through self-generation of power.

The prospects for advanced, high-efficiency gas turbines remains dependent on environmental performance and pricing. The oil and gas industry has historically been slow to embrace new technologies, and will remain so in the increasingly competitive market. Environmental performance will gain increased importance relative to operating cost through the year 2000 and beyond. At the same time, increased competition will force operators to plan and operate more efficiently, reducing manpower and reducing maintenance to lower costs. These factors favor gas turbine compressors over reciprocating engines in purchase decisions.

Manufacturing Industries. The industrial sector represents the single largest consumer of energy, accounting for $36 \%$ of total end-use energy consumption in this country. Opportunities for the industrial ATS include direct mechanical drive, cogeneration, and selfgeneration of electrical power.

Solar's recuperated industrial ATS can be directly applied to all cogeneration applications including Non-Utility Generators (NUGs). Considering the high electrical-to-thermal (E/T) production ratio, the ATS is best suited to industries with comparable electric and thermal requirements.

For industries requiring only electricity, the industrial ATS can be a significant opportunity to "self-generate" electricity at a lower cost than can be obtained from local electric utilities. These industries include the primary metals industry (steel, fabricated metals), paper, textiles, chemicals and petroleum refining.

Primary Metals Industry. The primary metals industry was the third largest user of total primary energy in 1985 , consuming 3.23 quads, or about $15 \%$ of the total manufacturing sector. U.S. Primary Metals Industry Energy Use is summarized in Table 5.

Factors affecting system choices include the cost of power, reliability, and environmental emissions. Given the intense global competition, it is imperative that metals manufacturers keep the cost of production to a minimum. Reliability is critically important, since in some cases there are no backup systems in place, and unanticipated shutdowns can be very costly. Environmental emissions has become a critical issue for the metals industry. Despite efforts by the industry as a whole, dependence on fossil fuels (principally coke, coal and related waste fuels) continues to create problems as standards for air emissions become more stringent. Because U.S. integrated steel mills are generally located in environmentally-sensitive areas (i.e., non-attainment areas) in states such as Pennsylvania, Ohio, Indiana, and Illinois, plant expansion is nearly impossible with current technology.

Opportunity for the ATS within the primary metal industry is good, given the increasing trend toward electrification. Each industry segment may not be growing rapidly, but there is a structural shift occurring, particularly within the steel industry, favoring the industrial ATS between the 5 and $20 \mathrm{MWe}$ size range. 
Table 5. U.S. Primary Metal Industry Energy Use, 1988

\begin{tabular}{||l|r|r||}
\hline \multicolumn{1}{|c|}{ Energy Source } & $\begin{array}{r}\text { Energy Use } \\
\left(\mathbf{1 0}^{12} \mathbf{B T U}\right)\end{array}$ & Percent of Total \\
\hline Electricity & $1,408.8$ & 43.1 \\
Natural Gas & 685.2 & 21.0 \\
Coke/Breeze & 580.7 & 17.7 \\
ByProducts & 404.0 & 12.3 \\
Coal & 56.8 & 1.7 \\
Other & 50.0 & 1.5 \\
Fuel Oil & 41.0 & 1.3 \\
Residual Oil (No. 6) & 27.4 & 0.8 \\
Distillate Oil (No. 2) & 13.6 & 0.4 \\
Liquified Propane Gas & 1.0 & 0.0 \\
& & 100.0 \\
Total: & $3,268.5$ & \\
\hline
\end{tabular}

Note: Electricity converted at 10,500 Btu/kWh

The fabricated metals industry (i.e., metal cans, tinware, handtools, cutlery, general hardware, etc.) is a relatively small user of total primary energy, consuming less than $2 \%$ of the total manufacturing sector in 1985. Decision criteria affecting energy system choices are roughly the same as for the primary metals industry (cost of power and reliability, primarily, with a consideration of fuel availability taking importance over emissions, since the industry relies on natural gas and electricity for manufacturing).

Cogeneration activity within this industry is low, and nearly all units are natural gas-fired. Natural gas is expected to continue to dominate this industry well into the 21st century.

Little growth is expected in this industry segment over the next ten to twenty years, but increased electrification should provide ATS some opportunity.

The paper and allied products industry (processing wood, waste paper and other cellulose fibers into pulp and paper products). This industry produces thousands of end-use products, ranging from writing paper and newsprint to paperboard and particleboard. The industry is comprised of four major segments: pulp mills, paper mills, paperboard mills and paperboard containers and boxes, and is the fourth largest user of total primary energy in 1985 , consuming 2.21 quads or $12.6 \%$ of the total manufacturing sector.

Energy use by the paper industry has increased over the past decade, and the industry continues to move toward the increased use of recycled fibers. The paper industry has a long established history of self-generation, given the availability of waste fuel, but the availability of low cost waste fuel is declining. Trends toward cogeneration applications, 
particularly those with higher proportion of electrical output will benefit industrial ATS, especially the "enhanced" ATS simple cycle system.

Textile Industry. The U.S. textile industry processes raw materials such as cotton, wool and synthetic fibers into yam and finished fabrics. Products of textile mills are primarily the fabrics which other industries convert into apparel, household products (floor coverings, carpets and rugs) or commercial or industrial products.

The primary use for energy systems in the textile industry is for cogeneration. Primary equipment purchase decision criteria include: part load efficiency, the cost of power, reliability, and environmental compliance due to reliance on fossil fuels.

The outlook for the ATS enhanced simple cycle is generally good for cogeneration. Industry demands for electrical energy are high, and there is a history of self-generation. Opportunities for the ATS are probably best at the 2 to 20 MWe range.

Chemicals Industry. Three general classes of products comprise the chemicals industry: basic chemicals (acids, alkalies, salts and organics), intermediate products (synthetic fibers, plastics, colors and pigments), and finished products (drugs, cosmetics, soaps, fertilizers and explosives).

The chemicals industry was the second largest user of total primary energy in 1985, consuming 3.57 quads (at $3,412 \mathrm{Btu} / \mathrm{kWh}$ ), or $20.4 \%$ of the total manufacturing sector. Chemical industry energy use decreased over the past decade due to increased energy efficiencies. Natural gas and electricity comprise $72 \%$ of all energy consumed by this industry.

The primary use for power systems within the chemicals industry is in cogeneration, either in conjunction with mechanical drive or electricity generation. Factors affecting system choices include the cost of power, reliability and environmental compliance, since despite efforts to achieve compliance by the chemicals industry, it is still highly dependent on fossil fuels for process energy generation. This, in turn, has limited expansion of production capabilities at existing plants.

The high rate of growth in electricity demand for the chemical industry indicates positive opportunities for the ATS. Considering the requirement for large steam loads, and that technology will overcome reliability perception hurdles, there is opportunity for the ATS in mechanical drive applications.

Petroleum Refining Industry. Including establishments converting crude oil into useful products (asphalt, paving and roofing materials as well as miscellaneous products of petroleum and coal), the most significant segment of the industry remains petroleum refining. The industry was the largest user of total primary energy in 1985, consuming 5.123 quads (at $3,412 \mathrm{Btu} / \mathrm{kWh}$ ) or $29.3 \%$ of the total manufacturing sector. The industry is the third largest cogenerator of electric power. 
Within the petroleum refining industry as a whole, the primary use for power systems is cogeneration, either in conjunction with mechanical drive or electricity generation. Primary factors affecting system choice include: the cost of power (high energy intensity within this industry makes control of process energy critically essential.), reliability, and environmental compliance.

The refining industry is not expected to grow significantly, however there are considerable opportunities for the ATS resulting from industry restructuring underway. Environmental compliance is becoming an important consideration (due to industry-wide reliance on fossil and waste fuels for process energy generation as well as feedstock, which continues to inhibit expansion of production capability at existing plants, and is forcing considerable amounts of retrofitting and replacement of equipment. Increased electricity use in refining processes may lead to opportunities for ATS either on-site or in utility generation.

Mechanical Drive Applications. Mechanical drive applications are defined as those in which shaft power from a driver is used by a mechanical device other than an electric generator. Large applications within industry include pumps, compressors and blowers.

Most of the opportunity for the ATS lies within selected processes in the chemicals, petroleum refining and steel industries, and falls within the $7,000 \mathrm{hp}$ and $33,000 \mathrm{hp}$ range. Within the chemicals industry, several key product/process segments made extensive use of large mechanical drive units. These include ethylene/propylene, ammonia, methanol, urea, and nitric acid. Petroleum refining also requires use of mechanical drives in the size range greater than $10,000 \mathrm{hp}$. Catalytic cracking, alkylation and fluid coking are processes likely to be found at any given refinery, and require mechanically-driven processes.

Integrated steel mills also utilize mechanical drive applications running between 7,000 hp and $33 \mathrm{khp}$, driving turbo-blowers for blast fumaces. Structural changes within the steel industry, including a widespread switch to the use of electric arc furnaces in steel minimills, indicate that there will be little, if any increase in the capacity of integrated steel mills. Consequently, market opportunities for the ATS will be mainly limited to replacement of existing mechanical drives.

\subsection{MACRO-CHARACTERIZATIONS PER PRIMARY MARKET}

General Market Trends (Electric Utility industry). Changes in the utility industry coupled with ongoing developments to industrial gas turbine technology are opening up a huge market opportunity for distributed generation, a prime candidate application for the ATS. Increasing competition for energy senvices at the retail level, continuing electric utility industry restructuring, projections for higher fuel prices, a recognition of the efficiency and cost benefit of local generation, the environmental movement toward energy efficiency and pollution prevention, and advancements in small power technology are all factors which could make small power a serious contributor to the future power generation mix in this country.

Regulatory and Legislative Drivers. During the 1970's, a number of market events occurred which caused a reversal in electric utility economic trends. Contributing factors 
were the energy crises of 1973 and 78 , increased environmental control costs, significant over capacity, stalled or delayed nuclear plant construction, and escalating non-fuel Operation and Maintenance (O\&M) Costs for coal and nuclear plants. The bottom line was a doubling of electricity prices in real dollars.

These trends, coupled with ever-increasing environmental pressures, induced major legislative and regulatory initiatives which altered the course of the electric industry.

Oil and Gas Macro Trends. The oil and gas production and transmission industries are already quite familiar with the concept of distributed generation, and have expressed a strong interest in the size of power generation equipment defined by the ATS. Since the industries are already quite familiar with the technology used in the recuperated gas turbine engine, it's an attractive, low-risk product.

The U.S. oil and gas industries are not expected to open any significant numbers of new oiffields, nor are they expected to make any large investments in opening up new natural gas fields. However, it is expected that the industry as a whole will be taking a look at the possibilities within the newly-deregulated electric power generation field, offering alternative sources of fuel to non-utility markets.

Cogeneration Market Trends. The cogeneration advantage is intrinsically high overall efficiencies when recovered heat can be effectively utilized to displace boiler or process fuel requirements. In the 1980's and early 1990's, non-utility wholesale electric generation and not retail cogeneration made the big inroads. However with low gas prices, economics of precision for small plants are winning out over high thermal utilization.

The three dominant cogeneration user groups (paper, chemicals and refining) represent 52 percent of the capacity in the $1-40 \mathrm{MW}$ size range. Other very significant market sectors include agricultural and food, other industrial, and commercial/institutional facilities The "other industrial" category consists of lumber, fabrication manufacturing, district heating, and water-to-energy plants.

By creating a value for recovered heat, small generators can overcome the inherent cost and shaft efficiency disadvantage relative to large central station combined cycle plants.

\subsection{MICRO-CHARACTERIZATIONS PER PRIMARY MARKET SEGMENT}

Commercial Sector Segment. As discussed in Section 3.2, multi building commercial facilities with central physical plants represent potential opportunities for cogeneration, and for prime mover driven cooling equipment. Steam uses for recovered exhaust heat include space heating, domestic hot water and absorption cooling.

Electric rate structures are shifting an ever-increasing share of the cost of electricity to the peak user, driving up the operating cost of conventional electric cooling.

Furthermore, the aging stock of central plant HVAC equipment, coupled with mandated phase out of CFC's will drive an unprecedented chiller replacement market beginning in 
the mid 1990's. This window of opportunity for gas turbine driven chiller equipment should last for about ten years, into the year 2005. Furthermore, central utility plant expansions and refurbishment represent ideal times to consider adding cogeneration as the incremental cost is more manageable than if only cogeneration were being considered on a retrofit basis. 


\subsection{ATS MARKET POTENTIAL: 3 SCENARIOS}

To provide a framework for developing and describing the ATS market potential, three potential scenarios are outlined. By evaluating the market potential for the ATS under alternate scenarios, the stability of the ATS market can be assessed.

Information from three organizations was used to construct these scenarios: the American Gas Association (AGA), the Gas Research Institute (GRI) and the Department of Energy's Energy Information Administration (EIA). Although each organization's forecast generally rely on the same historical data, the individual forecasts differ dramatically along several dimensions important to the ATS market potential.

Table 6 illustrates the many market opportunities for the industrial ATS, while the following exhibits (Table 7) compare the different interpretations of data available.

Table 6. Market Opportunity and Application of ATS

\begin{tabular}{|c|c|c|c|c|c|c|c|}
\hline MARKETS & & & & & pplica & & \\
\hline $\begin{array}{l}\text { INDUSTRIAL } \\
\text { Oil \& Nalural Gas } \\
\text { Mining } \\
\text { Petro Chemical } \\
\text { Chemical } \\
\text { Food \& Agricultural } \\
\text { Process } \\
\text { Pulp, Paper, Wood } \\
\text { Pharmaceutical } \\
\text { Primary Metals } \\
\text { Cement, Tile, Ceramic } \\
\text { Textile } \\
\text { Manufacturing } \\
\text { COMMERCIAU } \\
\text { INSTITUTIONAL } \\
\text { Communications } \\
\text { Finance/Banking } \\
\text { Universities/Colleges } \\
\text { Hospitals } \\
\text { Airports } \\
\text { Buildings/Facilities }\end{array}$ & $\begin{array}{l}0 \\
0 \\
0 \\
0 \\
0 \\
0 \\
0 \\
0 \\
0 \\
0 \\
0\end{array}$ & $\begin{array}{l}0 \\
\bullet \\
\bullet \\
0\end{array}$ & $\begin{array}{l}x \\
x \\
x \\
X \\
X \\
X \\
X\end{array}$ & $\begin{array}{l}x \\
x\end{array}$ & $\begin{array}{l}x \\
x\end{array}$ & $\begin{array}{l}x \\
x \\
x \\
x \\
x \\
x \\
x\end{array}$ & $\begin{array}{l}\text { G,S } \\
\text { S,A } \\
\text { G,S } \\
\text { S,A } \\
\text { A,S } \\
\text { S } \\
\text { G,S,A } \\
\text { A } \\
\text { S,A } \\
\text { S,A } \\
\text { S,A }\end{array}$ \\
\hline $\begin{array}{l}\text { trial } \\
\text { Market }\end{array}$ & \multicolumn{7}{|c|}{$\begin{array}{l}\text { A }=\text { ATS Growth Opportunity } \\
S=\text { Solar is Gas Turbine Share Leader } \\
G=\text { Primary Power Supply } \\
X=\text { Current and Potential Applications }\end{array}$} \\
\hline
\end{tabular}


Table 7. Exhibits from RDC Report

\begin{tabular}{|c|c|c|c|c|c|c|c|c|c|}
\hline \multirow[b]{3}{*}{ Scenario } & \multicolumn{8}{|c|}{ Summary of U.S. Primary Energy Use by Scenario (Quadrillion Btu) } & \\
\hline & \multicolumn{3}{|c|}{1995} & \multicolumn{3}{|c|}{2000} & \multicolumn{3}{|c|}{2010} \\
\hline & Natural Gas & Electricity & Total & Natural Gas & Electricity & Total & Natural Gas & Electricity & Total \\
\hline AGA TERA & 22.0 & 34.9 & 89.6 & 23.6 & 37.6 & 91.4 & 26.1 & 39.9 & 95.6 \\
\hline GRI Baseline & 21.0 & 32.6 & 88.6 & 22.8 & 34.8 & 93.1: & 26.0 & 41.9 & .103 .3 \\
\hline EIA Reference & NA & NA & NA & 22.7 & 34.3 & 95.7 & 24.9 & 37.7 & 105.2 \\
\hline
\end{tabular}

Electricity Note: AGA TERA and GRI Baseline include fuels used for cogenerated electricity, whereas EIA excludes cogenerated electricity which roughly accounts for less than 0.5 quadrillion Btu's.

Basic U.S. Economic and Energy Scenario Parameters

\begin{tabular}{|c|c|c|c|c|c|c|c|c|c|}
\hline \multirow[b]{2}{*}{ Scenario } & \multicolumn{3}{|c|}{$\begin{array}{l}\text { GDP Price Deflator } \\
(\% / y r)\end{array}$} & \multicolumn{3}{|c|}{$\begin{array}{l}\text { Crude Oil [Refiners Acquisition] } \\
\text { (\$/barrel) }\end{array}$} & \multicolumn{3}{|c|}{$\begin{array}{l}\text { Natural Gas [Field Acquisition } \\
\text { (\$/Mcf) }\end{array}$} \\
\hline & $95-00$ & $01-05$ & $06-10$ & 1995 & 2000 & 2010 & 1995 & 2000 & 2010 \\
\hline AGA TERA & $4.0 \%$ & $4.4 \%$ & $4.6 \%$ & 17.65 & 22.00 & 25.00 & 2.30 & 2.65 & 3.15 \\
\hline GRI Baseline & $2.7 \%$ & $2.0 \%$ & $2.0 \%$ & 19.99 & 21.69 & 27.88 & 2.14 & 2.56 & 3.19 \\
\hline EIA Reference & $2.6 \%$ & $3.3 \%$ & $3.5 \%$ & NA & 21.34 & 29.00 & NA & 2.49 & 2.98 \\
\hline
\end{tabular}

GRI Note: GDP Deflators for "01-05" and "06-10" periods are based on average annual GDP deflator for "01-10" period.

Sources: "GRI Baseline Projections of U.S. Energy Supply and Demand to 2010", Gas Reasearch Institute, Volumes 1 and II, 1994; "1994 Policy Implications of GRI Baseline Projection of U.S. Energy Supply and Demand to 2010", Gas Reasearch Institute, 1994; "Annual Energy Outlook 1994 With Projections to 2010", Energy Information Administration, 1994;

"A.G.A. TERA Demand/Marketplace", American Gas Association, Released January 1994. 
Table 7. Exhibits from RDC Report (Continued)

\section{Comparative Natural Gas Demand Forecasts for Key ATS Markets}

\begin{tabular}{|c|c|c|c|c|c|c|c|c|c|}
\hline \multirow{2}{*}{ Scenario } & \multicolumn{3}{|c|}{ ELECTRIC POWER SECTOR } & \multicolumn{3}{|c|}{ PIPELINES/STORAGE SECTOR } & \multicolumn{3}{|c|}{ MANUFACTURING SECTOR } \\
\hline & Utilities & NUGS & Total & 1995 & 2000 & 2010 & Cogen & Mech. Drive & Total \\
\hline AGA TERA & & & & & & & & & \\
\hline -Gas (TBtu/yr) & & & & 685 & 643 & 567 & NA & NA & NA \\
\hline $1995-2000$ & 421 & 396 & 817 & & & & & & \\
\hline $2000-2005$ & 427 & 404 & 831 & & & $:$ & & & \\
\hline $2005-2010$ & 454 & 157 & 611 & & & & & & \\
\hline -Capacity (MWe) & & & & NA & NA & $\mathrm{NA}$ & NA & NA & NA \\
\hline $1995-2000$ & 29,308 & 18,167 & 47,476 & & & & & & \\
\hline $2000-2005$ & 19,104 & 16,561 & 35,665 & & & & & & \\
\hline $2005-2010$ & 17,833 & 5,387 & 23,219 & & & & & & \\
\hline GRI Baseline & & & & & & & & & \\
\hline -Gas (TBtu/yr) & & & & 742 & 814 & 924 & & & \\
\hline $1995-2000$ & 468 & 153 & 621 & & & & 246 & NA & NA \\
\hline $2000-2010$ & 48 & 369 & 416 & & & & 314 & $\mathrm{NA}$ & NA \\
\hline -Capacity (MWe) & & & & $\mathrm{NA}$ & NA & NA & & & \\
\hline $1995-2000$ & 15,100 & 7,072 & NA & & & & 2,055 & NA & NA \\
\hline $2000-2010$ & 14,700 & 10,290 & NA & & & $\therefore$ & 3,060 & $\mathrm{NA}$ & $\mathrm{NA}$ \\
\hline ELA Reference & & & & & & & & & \\
\hline -Gas (TBtu/yr) & & & & NA & 691 & 727 & & & \\
\hline $1995-2000$ & NA & NA & NA & & & & NA & NA & NA \\
\hline $2000-2005$ & 470 & 400 & 870 & & & & 525 & $\mathrm{NA}$ & NA \\
\hline $2005-2010$ & (340) & 200 & (140) & & & & 494 & $\mathrm{NA}$ & NA \\
\hline -Capacity (MWe) & & & & NA & NA & NA & & & \\
\hline $1995-2000$ & NA & $\mathrm{NA}$ & NA & & & & NA & NA & NA \\
\hline $2000-2005$ & 18,320 & 10,300 & $\mathrm{NA}$ & & & & 500 & $\mathrm{NA}$ & NA \\
\hline $2005-2010$ & 10,160 & 10,770 & $\mathrm{NA}$ & & & & 480 & $\mathrm{NA}$ & $\mathrm{NA}$ \\
\hline
\end{tabular}

General:

NOTE: All depicted natural gas consumption projections are "net" changes in annual use of natural gas.

All depicted "utility" capacity forecasts are planned capacity additions during period indicated.

AGA Notes:

NUG forecasts depict only that for electricity sales to utilities.

GRI Notes:

Utility electric capacity additions depicted above as natural gas-fired are classified as both natural gas-fired and oil-fired capacity additions by GRI. GRI baseline does not provide forecasts for 2005 for the information depicted above. Natural gas-fired capacity additions presented above for "Utilities" in 1995-2000 period are GRI forecasts for 1992-2000 period. Natural gas-fired capacity increases presented above for "NUGs" are GRI forecasts for net increases in NUG natural gas-fired and oil-fired NUGs engaged in sale of electricity to utilities. Depicted forecasts for natural gas used in cogeneration is that "attributable to electricity generation" only. Projections of cogeneration capacity are net additions of on site dedicated capacity over subject time period.

EIA Notes:

All electric power capacity depicted is comprised of "Combined Cyclen and "Combustion Turbine/Diesel" using natural gas and oil as fuels. Natural gas-fired "Utility" capacity additions, whereas natural gas-fired "NUG" capacity are net changes in installed capacity over period indicated. In addition, "NUG" capacity excludes cogeneration, whose primary functions is not electricity generation. 
Table 7. Exhibits from RDC Report (Continued)

U.S. Fuel Price Projections 2000 - 2010

(All Prices in \$ 1993 per MMBtu)

\begin{tabular}{|c|c|c|c|c|}
\hline GRI 1994 Baseline & 1992 & 2000 & 2005 & 2010 \\
\hline \multicolumn{5}{|l|}{ Natural Gas } \\
\hline Industrial & 2.57 & 3.33 & 3.62 & 3.94 \\
\hline Utility & 2.47 & 3.18 & 3.46 & 3.78 \\
\hline Wellhead & 1.91 & 2.56 & 2.86 & 3.19 \\
\hline \multicolumn{5}{|l|}{ Electricity } \\
\hline Industrial & 15.01 & 14.48 & 14.33 & 14.18 \\
\hline
\end{tabular}

\begin{tabular}{|lrrrr|}
\hline DOE 1994 Reference & $\mathbf{1 9 9 2}$ & $\mathbf{2 0 0 0}$ & $\mathbf{2 0 0 5}$ & $\mathbf{2 0 1 0}$ \\
\hline Natural Gas & & & & \\
Industrial & 3.16 & 3.97 & 4.51 & 5.08 \\
Utility & 2.35 & 3.01 & $\ddots .3 .62$ & 4.21 \\
Wellhead & 1.92 & 2.42 & 3.08 & 3.58 \\
Electricity & & & & \\
Industrial & 15.33 & 15.49 & 15.79 & 16.61 \\
\hline
\end{tabular}

\begin{tabular}{|lcccc|}
\hline AGA/TERA 1993 Base Case & $\mathbf{1 9 9 2}$ & $\mathbf{2 0 0 0}$ & $\mathbf{2 0 0 5}$ & $\mathbf{2 0 1 0}$ \\
\hline Natural Gas & & & & \\
Industrial & 2.92 & 3.27 & 3.42 & 3.57 \\
Utility & 2.42 & 2.99 & 3.20 & 3.41 \\
Wellhead & 1.83 & 2.57 & 2.82 & 3.06 \\
Electricity & & & & \\
Industrial & 14.88 & 13.71 & 13.30 & 12.59 \\
\hline
\end{tabular}


Summarized below are the differences and similarities between the three forecasts, and how these differences will affect the ATS market potential.

- Environmental Law and Regulations. Each organization addressed all elements of the Amendments to the Clean Air Act (1990), and all pertinent environmental provisions of the Comprehensive National Energy Policy Act of 1992 (EPAct). All three forecasts assume full compliance with environmental regulations.

- Energy Market Dynamics. The three forecasts differed in their prediction of the demand for, and price of natural gas and electricity. The demand for gas will provide partial insight (mainly for gas transmission requirements), into the technical market size in which the ATS can compete. The prices for natural gas and electricity will play an instrumental part in determining ATS economic competitiveness in these markets. The three organizations predicted "business as usual," within the oil storage and transmission industry - implying no profound structural changes were expected in the industry, nor any dramatic changes in the demand for oil in the U.S.

- Utility Regulation and Electric Power Industry Restructuring. Each forecast incorporated the current regulatory programs that promote power plant repowering, life-extensions and productivity improvements. In addition, each included extensive treatment of energy conservation, load management and demand-side management as an extension of current programs. Each assumed continued expansion of the use of integrated resource planning as part of increased reliance on commpetitive bidding for power supply (or reduced demand) between utility and non-utility sources.

However, none of the organizations fully evaluted the implications of restructuring the electric utility industry, i.e., "unbundling" generation, transmission and distribution functions, and "retail wheeling" for electricity. Additionally, none of the three studies mentioned the emergence and expected growth of the distributed power generation segment of the U.S. electric power industry. The AGA did reveal expectations that the U.S. electric power industry may undergo structural changes leading to increased natural gas use in the electric power industry. Likewise, none of the studies mentioned fundamental changes in the U.S. manufacturing sectors which could affect continued growth in self-generation for both cogeneration and mechanical drive applications.

Additional studies were conducted and construct two extreme scenarios capturing the differences in technical parameters contained in the three forecasts. Further studies were performed to establish power capacity distributions required over the 2000-2010 time period. These studies indicate that:

- The demand for power generation capacity over the 2000-2010 period which can be served by natural gas-fueled gas turbine technology, where site- 
specific requirements are less than $100 \mathrm{MWe}$ and greater than $5 \mathrm{MWe}$ provides great opportunity for ATS. This estimate represents less than 20 percent of the total demand of all power generation capacity in all U.S. market segments over the same time period.

- The total applicable technical market of $11.6 \mathrm{GW}$ is the demand for power generation capacity over the 2000-2010 period which can be served by ATS units not exceeding the maximum number of units per application.

- In the smaller size ranges (below $10 \mathrm{MWe}$ ), over 55 percent is in the distributed power generation segment, nearly 30 percent is in oil and gas storage and transmission and 15 percent in manufacturing industry selfgeneration.

\subsection{MARKET VARIABLES}

Market variables that can significantly impact the market penetration of the Industrial ATS into each of the target market segments include:

- Fuel Price Changes. Within each of the scenarios defined, the economic attractiveness of an Advanced Turbomachinery Systems varies no more than 3 percent between 2000 and 2010. Between the scenarios described, the differences in economic attractiveness vary by no more than 6 percent.

- Commercial Availability. All advanced technologies currently under development were assumed to be commercially available in the market beginning in 2000 , at the costs and performances specified for a mature technology per several sources studied.

- Market Acceptance. No penalties were assigned on "new" technologies for this study (including the ATS). These considerations include many market phenomena, including buyer risk aversion to "new" technologies, buyer awareness, and learning curves. For most technologies, the issue of market diffusion is, to a large extent, under the control of the technology vendor, and is critically dependent on a strategic commercialization program well in advance of actual market introduction to increase the market's reception of the new technology.

Market penetration rates for this study, are assumed to remain consistent with economic market results, and are depicted in Table 8. 
Table 8. U.S. ATS Market Forecast (2000 - 2010)

\begin{tabular}{|l|c|c|c|c|c|}
\cline { 2 - 6 } \multicolumn{1}{c|}{} & $2000-2001$ & $2002-2003$ & $2004-2005$ & $2006-2010$ & TOTAL \\
\hline Oil \& Gas Transmission (hp) & 314,004 & 326,690 & 339,888 & 721,525 & $\mathbf{1 , 7 0 2 , 1 0 7}$ \\
\hline Electric Power Generation*(kW) & $1,511,286$ & $1,572,342$ & $1,635,865$ & $3,472,666$ & $\mathbf{8 , 1 9 2 , 1 5 8}$ \\
\hline TOTAL (kW) & $1,745,533$ & $1,816,052$ & $\mathbf{1 , 8 8 9 , 4 2 1}$ & $\mathbf{4 , 0 1 0 , 9 2 4}$ & $\mathbf{9 , 4 6 1 , 9 3 0}$ \\
\hline
\end{tabular}

Note: Includes mechanical drive for manufacturing industries.

Source: RDC, Inc. 


\subsection{CONCLUSIONS AND RECOMMENDATIONS}

This section summarizes the ability of the chosen ATS configuration to compete for high market placement relative to its competitors, and its ability to meet the buying criteria of the many market end users. Market estimates are illustrated, and the commercial opportunities and challenges to obtaining high market placement are detailed.

RDC's and Onsite's Market Studies call attention to the fact that the market sectors in which the ATS will compete will have contrasting needs. Both the demonstration ATS System, with recuperated cycle turbine prime movers, and Solar's enhanced simple cycle turbines will participate in the market, broadening the opportunity for energy savings and environmental emission reduction.

Together these product lines (the ATS recuperated and the enhanced, derivative simple cycle) will meet or exceed the buying criteria outlined by the various global markets.

The features and benefits of the Solar ATS will take a large share in the 3 to $20 \mathrm{MW}$ size range. The technical markets, as defined in the RDC Market Study, looked at twelve distinct market sectors and applications, and concluded that the ATS in the smaller size range was well-suited for the intermediate load (1500 to $3000 \mathrm{hrs}$ per year) systems, and the mechanical drive markets.

Competitive technologies to the ATS in the industrial ATS-size class will not offer significant rivalry for the bulk of the potential market. The ATS should be highly competitive, taking a large share in the 3 to $20 \mathrm{MW}$ size range, until the time when the first cost as well as the life cycle cost of fuel cells or photovoltaic make a major breakthrough, providing a substantial cost savings.

New markets in the US for Utility Distributed/Dispersed generation will be a major market opportunity, and there will be an increased demand for industrial rated cogeneration systems. North American transmission activity will increase to serve the expanded use and choice of natural gas over higher emission by-products fuels. The Oil Industry will look at replacing or upgrading simple cycle Solar products. 


\section{APPENDIX A \\ DESCRIPTION/DEFINITION OF SOLAR'S ADVANCED TURBINE SYSTEMS}

Solar's ATS is a gas-fired power generation system driven by a recuperated gas turbine engine, as shown in Figure A-1 and will be scaled to meet the possible ranges of industrial power generation requirements identified by a broad spectrum marketplace.

Table A-1 lists system elements, features and benefits of the Advanced Turbine System that Solar is developing.

The basic Solar ATS is scalable to various power levels to further meet the variety of power needs of industrial size class users as dictated by customer buying criteria research across several market sectors. Sizes other than the initial ATS offering will be defined and developed as market studies, customer feedback and power requirements are defined. In this manner, market penetration by the Solar ATS will be maximized.

As well as introducing a new family of recuperated ATS products, Solar intends to place ATS technologies in its existing line of Solar gas turbine systems. Additionally, the opportunity to retrofit currently-placed Solar gas turbine systems with appropriate technology that will enhance the economic and/or technical performance (modifications

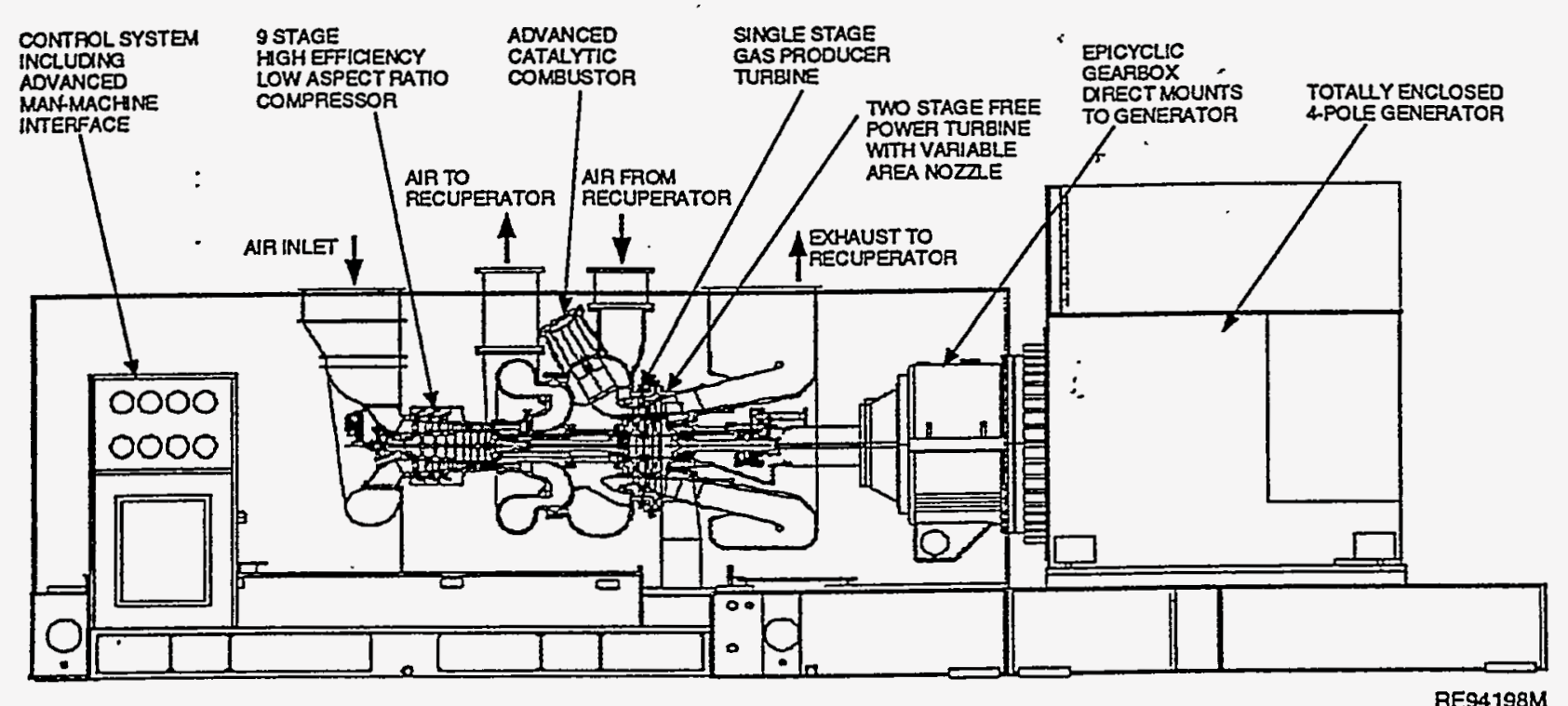

Figure A-1. Solar's ATS: Core of a Family of Advanced turbine Systems 
Table A-1. Features and Benefits of Solar's ATS

\begin{tabular}{|c|c|}
\hline System Element and Features & Benéfits \\
\hline $\begin{array}{l}\text { Gas Turbine Engine: } \\
\text { Single spool, } 2 \text { shaft, recuperative cycle } \\
-8.92: 1 \text { pressure ratio }(\mathrm{PR}) \\
\text { - } 1186-1204^{\circ} \mathrm{C}\left(2166-2200^{\circ} \mathrm{F}\right) \text { turbine inlet temperature } \\
\text { - } 9 \text { stage axial compressor } \\
\text { - Primary surface recuperator (PSR) } \\
\text { - Can-annular combustor, ceramic liner } \\
\quad \text { catalytic } \\
\text { ultra lean premix (ULP) } \\
\text { - } 1 \text { stage gas producer turbine, ceramic tipshoe, blades } \\
\text {-2 stage power turbine with variable nozzle }\end{array}$ & $\begin{array}{l}\text { - Max. market acceptance (best availability and emissions) } \\
\text { - Large retrofit potential } \\
\text { - Cover maximum market range for commercialization } \\
\text { - Reduced risks to emissions goals (low PR) } \\
\text { - Reduced risk to RAMD (low PR, moderate TIT) } \\
\text { - Low first cost (low parts count) } \\
\text { - Low cost of power (low parts count) } \\
\text { - Low maint. costs (gain efficiency from static part) } \\
\text { - High efficiency } \\
\text { - Ultra low emissions } \\
\text { - Low emissions with fuel flexibility, backup to catalytic } \\
\text { - Option for users requiring proven technology } \\
\text { - Low cost (minimum parts), efficient (min. cooling req'd) } \\
\text { - High efficiency over wide load range }\end{array}$ \\
\hline $\begin{array}{l}\text { System and Controls: } \\
\text { - Direct coupled AC start } \\
\text { - AC gen. with overhung epicyclic gearbox } \\
\text { - On skid controls } \\
\text { - Advanced man-machine interface }\end{array}$ & $\begin{array}{l}\text { - Improved availability, reduced parts count } \\
\text { - Reduced first cost (lighter package) } \\
\text { - Reduced first cost, improved availability (less wiring) } \\
\text { - Reduced life cycle cost, ímproved availability (plant } \\
\text { management; predictive capability) }\end{array}$ \\
\hline $\begin{array}{l}\text { Field Support } \\
\text {-Customer Services Support Center } \\
\text {-Fast Field Response (FFR) }\end{array}$ & $\begin{array}{l}\text { - Improved availability (access to technical support, training) } \\
\text {-Improved availability (access to field technical personnel) }\end{array}$ \\
\hline
\end{tabular}

that improve efficiency, low emission combustion hardware, advanced turbomachinery control systems, etc.) of the product for the customer, willmean additional savings of fuel and reduction of emissions.

There are cases where high thermal loads, and low electrical requirements would call for a turbomachinery system where exhaust heat is not utilized in a recuperated cycle, but can be harnessed for efficient cogeneration. However, without the benefit of ultra low emissions, "smart" man-machine interface control subsystems, variable area nozzle on the power turbine, and other ATS technologies, the product would not be as favorably received by end users. Simply put, buyers of Solar gas turbine systems have come to expect that all the appropriate technology that Solar has developed will be in their purchased system, providing the highest value.

The Solar ATS will be the cleanest combustion-based system available, providing emission levels that meet the permit requirements in non-attainment areas (8 ppmv NOx).

The advanced exhaust-heat recuperator and high component efficiencies throughout the engine and system will lead up to 43.2 percent thermal efficiency at the Busbar terminals, at design point. There will be a little drop-off of efficiency across a wide load range (50-100 percent load). 


\section{PRELIMINARY SPECIFICATION FOR SELECTED ATS CONFIGURATION}

As shown in Figure A-1 a new, high efficiency nine-stage axial compressor is being developed through an internally funded technology program for the ATS. The combustion system is a seven-can annular design, using either an ultra-lean premix combustor or a catalytic combustion system, either of which is suitable for future incorporation of autothermal fuel reformation. A single stage gas producer turbine is adaptable to either ceramic or advanced cooled metal airfoils.

The two-stage, free power turbine has a variable area nozzle in its first stage for improved part-load thermal efficiency. All of the structural and dynamic elements of the design have evolved from the robust designs that Solar has successfully incorporated in past products. The Primary Surface Recureator is unmatched in industry and represents durable design in performance.

\section{TECHNICAL PERFORMANCE RELATED SPECIFICATIONS}

Current Technology Baseline. Most power generation systems driven by gas turbines are based on the so-called "simple cycle" (SC). Today's industrial simple cycle gas turbines are capable of delivering thermal efficiencies up to 32 percent (ISO Standard day, sea level conditions, no losses). It is technically feasible to achieve higher efficiency through very high pressure ratios (20:1 plus), and turbine inlet temperatures $\left(1370^{\circ} \mathrm{C} / 2500^{\circ} \mathrm{F}\right.$ plus). However, this goes beyond the practical limit for $\mathrm{SC}$ gas turbines because the incremental cost of increasing efficiency beyond this level is too high to justify. Further, these SC engines have RAMD characteristics that are unacceptable to industrial gas turbine markets. The high performance SC gas turbine is therefore not an attractive prospect for further development due to limited growth potential and characteristics that do not suit the needs of industrial users.

Develop New Primary Baseline for 21st Century. By establishing aggressive performance goals, the ATS Program will increase a new baseline for industrial gas turbine systems for the 21st Century. In order to make the ATS a commercial success, it is crucial that the ATS not only meet or exceed the DOE's requirements, but also satisfy the buying criteria of the industrial turbine end users.

In narrowing the concept selected for the ATS, Solar first examined each of the goals and requirements, and considered various gas turbine cycles with a potential for meeting ATS program goals. The potential candidate list was narrowed after a qualitative assessment of several factors such as: 1) the appropriateness of the cycle in terms of the end user's buying criteria, 2) the potential for meeting program goals and for future growth, 3) the probability of successful demonstration within the program's schedule, and 4) the expected level of funding.

Recuperated Cycle Chosen. The recuperated cycle was selected as the most favorable for the ATS due to the impact on early reliability, first cost, and customer acceptance of more complicated cycles. In the future, other efficiency-enhancing cycle modifications (such as intercooling) will become more attractive in the industrial turbine marketplace. 
The selected ATS system is an industrial power system based on a recuperated engine cycle. The engine is a single spool gas producer $(G)$ design, with a free power turbine. Solar's ATS cycle conditions represent a substantial increase in firing temperature (142$264^{\circ} \mathrm{C} / 256-476^{\circ} \mathrm{F}$ ) above current levels and therefore power, over today's industrial gas turbines.

Technology Innovations. Innovative technologies incorporated into this engine include the use of advanced materials such as ceramics, thermal barrier coatings, and mechanical sealing techniques designed to reduce cooling air requirements. Clearance control through face and brush seals will maintain close turbine blade-tip clearances, and dual property materials in the turbine disks and recuperator will be employed to meet the required characteristics of strength, oxidation resistance and affordability.

In addition, the entire gas turbine power system has been designed to keep parasitic losses to an absolute minimum. The Solar ATS has a low pressure ratio (9:1), making it economically adaptable to firing with low pressure fuels such as natural gas, biomass and coal-derived fuels.

Technical Information. Solar will achieve the high system efficiencies necessary to support the industrial user's needs through the use of an advanced recuperator, and through the innovative use of materials to achieve busbar efficiencies of up to 43.2 percent (45.5 percent ISO engines). Recovering waste heat -- whether through recuperators or via steam generators -- has been a mainstream practice at Solar, proven through the $\mathbf{5 6 5 0}$ gas turbine, several of which were installations including heat recovery after the recuperator.

Solar's axial compressor efficiencies will move into the 88 to 89 percent (adiabatic) range vs. $84-85 \%$ today. Component efficiencies have also been addressed, particularly that of the compressor, and takes advantage of developments within the internally-funded ACE Compressor Development Program.

The primary benefit of these improved thermal efficiencies is a reduction in the user's fuel costs, over the useful load range. Solar's ATS will deliver higher efficiency over the user load range (50-100 percent load), superior to that of the baseline engine.

Fuel Flexibility. The ATS will primarily be designed to utilize natural gas as a fuel source, but will also be adaptable to a wide range of fuels to meet customer specified requirements. Dual fuel or even multi-fuel capability are options that will broaden market applicability. While natural gas promises to be both readily available and relatively inexpensive into the predictable future, Solar has engineered adaptability to future firing with biomass and coal-derived fuels. This is being incorporated into the ATS engine. In addition to the various grades of natural gas, current Solar installations operate with 21 different fuels derived from such diverse sources as sewage, municipal waste and gob gas. These experiences will be applied in the design of the ATS to maintain a highly flexible fuel capability. 
Currently, coal consumption for electricity generation is the primary use of coal in the U.S., accounting for a greater share of U.S. primary energy production than any other fuel. This is expected to increase from a level today of 32 percent to 35 percent by 2010 . Solar anticipates that coal will need to be gassified for the ATS, to allow cleanup emission levels.

The ATS operating cycle optimizes low emissions, high availability, low cost of power, high thermal efficiency, and fuel flexibility. Solar's approach in maximizing program value through commercialization offers a summary of the key features and benefits inherent in the Solar ATS.

\section{ENVIRONMENTAL PERFORMANCE RELATED SPECIFICATIONS}

Solar's ATS will meet all of the environmental program goals outlined by the Dept. of Energy. Developing both Catalytic and an Ultralean Premix (ULP) Combustion System, Solar's goal is to achieve emissions levels of $5 \mathrm{ppmv}$ NOx, $10 \mathrm{ppmv}$ of $\mathrm{CO}$, and $10 \mathrm{ppmv}$ of UHC.

The use of ceramics is being studied for use within the ATS in order to mitigate liner and blade cooling requirements. Ceramics are also expected to reduce $\mathrm{CO}$ emissions by preventing flame quenching in the liner boundary layer. Further testing in the DOE/Solar CSGT Program will guide the application of ceramics in the ATS combustion system, and GP turbine.

Continuing pressure from the U.S. and the international community will provide additional incentives to conserve fossil fuels, and increase generation and utilization efficiencies. Among fossil-fuels, natural gas use will encounter somewhat less resistance than petroleum and coal because of the lower carbon content in natural gas, and because of the electrical efficiencies obtained from state-of-the-art combined cycle plants that use natural gas.

Low emissions is a criterion identified by customers as rapidly growing in importance as they make their buying decisions. In some regions (severe non-attainment areas) lowest achievable emissions rate (LAER) must be achieved, making this buying criterion a threshold requirement. In other areas, particularly outside the U.S. and other NAFTA countries, low emissions are less crucial in the purchase decision. However, the increasing importance of low emissions to industrial customers is evidenced by Solar's recent sale of 10 Mars units within the Republic of Russia, all of which were equipped at extra expense with Solar's SoLoNOx combustion system.

Noise Emissions Levels. As a distributed generation power source for utilities, ATS noise levels become an important issue. Many of the units that will be sited by utility companies will be located within communities, sometimes within a few hundred yards of commercial and residential buildings. For this reason, the level of noise is an important consideration in siting the equipment. Noise intensity will be no greater than $75 \mathrm{db}$ at 100 feet for the ATS. Physical dimensions will be comparable to similarly sized current (simple cycle) prdoucts. 


\section{ECONOMIC PERFORMANCE RELATED SPECIFICATION}

The purchase decision for an industrial gas turbine system is strongly affected by system first cost. Typically, less than 34 percent of the total system cost is accounted for by the core engine. Solar, is taking a systems approach, making efforts to control all the components of first cost.

Even though the ATS includes advanced pollution prevention technology and a recuperator module, first cost of the system will be slightly higher than currently available systems. Total cost of power (life cycle cost) will be considerably lower than that available with today's engines (Figure A-2). Solar's highly reliable support systems combine with low first cost and high recuperated engine efficiency to provide a balanced approach to minimizing the cost of power.

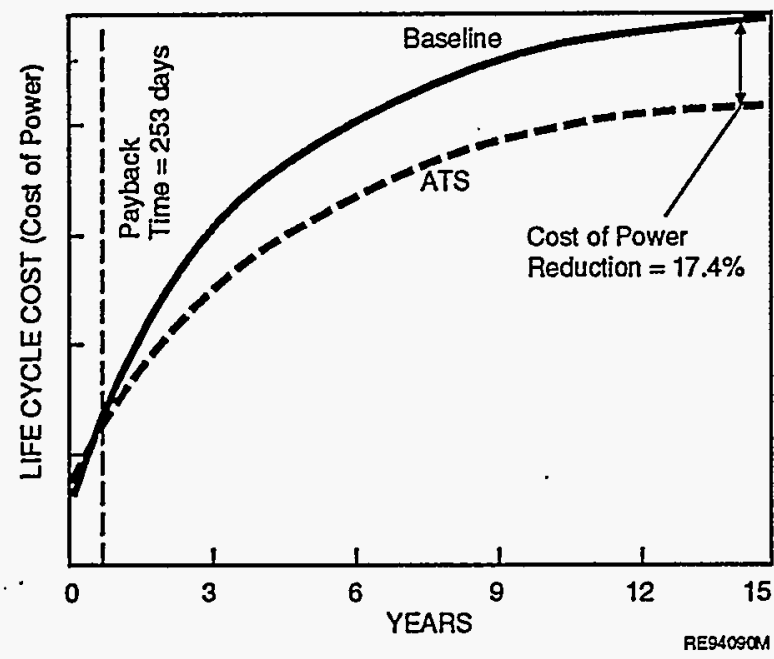

Figure A-2.

Solar's ATS Exceeds Goals for Reducing Cost of Power

The methods used in projecting costs and other economic issues such as operation and maintenance for the ATS, assure prospective customers they can realistically achieve a 10 percent or greater Life Cycle Cost (LCC) savings, and realize a competitive incremental Internal Rate of Return (IRR) by choosing the ATS technology instead of other existing turbine technology. In considering the greater risk associated with the new ATS technology, a concept of time value of money is used to measure the LCC savings and the incremental IRR. IRR is achieved by discounting the value of expected cash inflows and outflows by an increasing factor as the cash flows are expected further into the future. The sum of the discounted cash flows for the life cycle is referred to as the Net Present Value (NPV). Life cycle cost is a composite of several factors including, among others, first cost, operating cost (primarily fuel costs) maintenance costs and regulatory costs (permitting, emission controls, monitoring, etc.).

The two market studies undertaken reflect some differences in the projected market applications for the ATS. Generally, the customer can gain up to 17.4 percent LCC savings. Including minimal IRR installation costs for ATS technology, the results are an IRR on incremental investment that is well in excess of 100 percent. This is due to thermal 
efficiency improvements from roughly 29 percent to 43.2 percent generating approximately 14 percent to 20 percent in overall 15-year LCC savings. Most of the LCC savings flow through to the customer, so the price premium for choosing ATS technology is minimal. 


\section{APPENDIX B}

RDC REPORT

B-1 
B-2 


\section{ATS MARKET STUDY}

B-3 
1

B -4 


\section{EXECUTIVE SUMMARY}

RDC, Inc. ("RDC") was engaged by Solar Turbines, Incorporated ("Solar") to conduct a market study of the Industrial Advanced Gas Turbine System (ATS); to provide detailed information meeting the requirements of Task 5 of Phase II of the Solar-DOE co-sponsored Gas-Fueled Advanced Turbine System Development Program. Special emphasis was placed on the U.S. sector market opportunities. The Solar ATS is a gas-fired industrial turbine system based on technology capable of achieving efficiencies exceeding $40 \%$ with minimal emissions ( $<10$ ppmv $\mathrm{NO}_{\mathrm{x}}$ and $<20 \mathrm{ppmv} \mathrm{CO}$ ).

The potential ATS opportunities were identified and analyzed by the key characteristics of each primary market that could affect the industrial ATS commercial success. The data collected and analyzed assisted Solar in establishing industrial ATS performance characteristics important to the successful commercial deployment. RDC's market analysis provided Solar with sales projections for the industrial ATS in the U.S. and overseas.

To conduct the study, RDC used over 100 publications and the results of discussions with representatives of stakeholder organizations. In addition, RDC adapted computer models to conduct microsimulations of alternative industrial ATS in targeted applications, and developed alternative economic and technical scenarios to estimate the ATS forecasts in the U.S. Finally, data provided by Solar was incorporated concerning foreign industrial ATS markets.

The industrial ATS, a low-cost high-performance environmentally-compliant gas turbine, will make a profound impact on power generation in the 21st century as industry (especially, electric power industry stakeholders in the U.S. and Europe) will replace the "economies of scale" with "economies of precision" in technology investment. The industrial ATS surpasses the technical performance of power generation technologies currently used in small applications with dramatic increases in thermal efficiencies (e.g., $25 \%$ greater than conventional gas turbines) and the capability of meeting new, more restrictive emission standards (i.e., roughly $8 \mathrm{ppmv}$ and less for $\mathrm{NO}_{x}$ ) at equal or lower cost (i.e., levelized annual cost). The industrial ATS is a relatively simple system--devoid of the complexities and resource requirements (e.g., water) associated with many advanced technologies (e.g., steaminjected gas turbines, chemically recuperated gas turbines) which are often costly, impractical, if not unacceptable to users of small power generation applications.

The primary market applications in the U.S. for the industrial ATS after its commercial introduction in 2000 reside in the electric power generation (i.e., distributed baseload, intermediate, peaking and reserve generation), oil and gas storage and transmission (i.e., pumping and compression), and manufacturing (i.e., mechanical drive, self-generation).

Of the three market opportunities described, the emerging distributed generation industries represent the largest potential market for economically attractive industrial ATS deployment which could reach $13 \mathrm{GW}$ world wide over the $2000-2010$ period, and produce cumulative energy savings of nearly 300 trillion Btu (see Exhibit 1). Distributed generation is an 
emerging segment of the electric power generation industry whose growth is driven by the need to overcome technical deficiencies in existing electricity supply, prohibitive costs and schedule for expansion of transmission and distribution networks, regulations governing utility industry structure, competitive market forces that attract non-utilities to the electric power generation industry, and the replacement of "economies

Exhibit 1 Industrial ATS Market Summary

\begin{tabular}{|l|r|r|r|}
\hline Industrial ATS Market & $\begin{array}{c}\text { U.S. } \\
\text { Markets }\end{array}$ & $\begin{array}{c}\text { Foreign } \\
\text { Markets }\end{array}$ & $\begin{array}{c}\text { Market } \\
\text { Totals }\end{array}$ \\
\hline Total Installed Capacity: & & & \\
Oil \& Gas (khp) & 1,702 & 10,734 & 12,436 \\
Electric Power (MW) & 8,192 & 4,821 & 13,013 \\
Total Capacity (MW) & $\mathbf{9 , 4 6 0}$ & $\mathbf{1 2 , 8 1 8}$ & $\mathbf{2 2 , 2 7 8}$ \\
\hline Cumulative Energy Savings: & & & \\
Oil \& Gas (trillion Btu) & 26 & 111 & 137 \\
Electric Power (trillion Btu) & 203 & 93 & 296 \\
Total Energy Savings (trillion & $\mathbf{2 2 9}$ & $\mathbf{2 0 4}$ & $\mathbf{4 3 3}$ \\
Btu) & & & \\
\hline
\end{tabular}

of scale" by "economies of precision" in the selection and deployment of power generation technology. The industrial ATS is technically suited and cost competitive in all distributed generation functions (i.e., baseload, intermediate, peaking and reserve generation) regardless of ownership structure (e.g., independent power producers, non-utility generators, exempt wholesale generators, municipal utilities).

With over $8 \mathrm{GW}$ projected (or more than $60 \%$ of the world-wide total) for industrial ATS sales potential, the U.S. represents the largest geographical market. Based on published forecasts (e.g., EIA, GRI, AGA) for gas-fired electric power generation capacity in the U.S. over the 2000 - 2010 period, the industrial ATS capacity in distributed generation applications could represent roughly $15 \%$ of total capacity additions over the time period.

The oil and gas storage and transmission industries are traditional users of gas turbines and other fuel-fired prime movers which produce unacceptable emissions. Driven by expansion of pipelines, storage facilities, and opening new oil and gas fields, the industry is being seriously challenged in the U.S. and other highly industrialized countries to reduce air emissions at their pumping stations. The industrial ATS is technically suited and cost competitive in providing the industry with a reliable technology to meet environmental standards. Of the three primary markets, oil and gas storage and transmission is the second largest global market for the 
industrial ATS with a potential installed capacity of nearly 12.5 million horsepower over the $2000-2010$ time period, and cumulative energy savings of nearly 140 trillion Btu.

In contrast to the projections for the industrial ATS in distributed generation applications, the U.S. market for industrial ATS capacity for pumping applications at less than 2 million horsepower is less than $15 \%$ of projected global sales. However, sales for the industrial ATS could exceed $50 \%$ of the total capacity projected to be installed in the U.S. over the 2000 $2 \mathrm{G} 10$ period (e.g, GRI, AGA).

Self-generators in the manufacturing sector are traditional users of gas turbines and other prime movers for mechanical drive (e.g., pumps, compressors) and electric drive with and without cogenerated thermal energy used in processes. This segment of the manufacturing industry is forced to use self generation to overcome technical deficiencies and high cost associated with local electric utility service, and frequently finds cogeneration compatible with process thermal demands. Most candidate industries (e.g., chemicals, petroleum refining, textiles finishing) use large amounts of thermal energy and the continuing industry trends in electrification and steam conservation create opportunities well suited for the industrial ATS. With projections limited to the U.S., the sales of the industrial ATS reaches roughly 300,000 hp (or $225 \mathrm{MW}$ ) over the 2000 - 2010 period.

To exploit this opportunity, Solar Turbines must take advantage of its exceptional reputation and unique market position in the word-wide oil/gas industry to identify any and all opportunities--new and replacement--for its industrial ATS. It is crucial that Solar Turbines build an immediate presence and image in the "new" distributed electric power generation industry in the U.S. and abroad, since this industry will emerge during the remainder of the decade.

Despite the superior performance of the industrial ATS in most targeted market segments, Solar must pursue aggressive strategies with the objective to have the ATS become the "technology of choice," i.e., the "incumbent" in at least two key markets. To ensure the success of the industrial ATS in the U.S. and abroad, Solar must anticipate and be responsive to changes in the market which could represent challenges to the success of the industrial ATS.

In addition to pursuing its $R D \& D$ program to produce a commercially viable industrial ATS by the year 2000, Solar Turbines should aggressively proceed with activities designed to be strategically positioned in the emerging, high growth industrial ATS markets well before commercial introduction of the product. In discussions with representatives of stakeholder organizations, a few individuals indicated a willingness to explore possible arrangements with Solar even prior to the commercialization of the industrial ATS. 
While Solar has earned a unique and distinguished reputation in its traditional markets, the company is not yet as well-known in those markets which could contribute significantly to the success of the industrial ATS. Based on results of discussions with representatives of utilities and related organizations, Solar should begin efforts to establish an image in new markets equal to the image established in traditional markets (e.g., oil/gas industries). This would have the additional benefit for Solar in identifying "key" participants in these markets and gain a working knowledge of the market protocols and channels which have proven successful.

To enhance visibility and ensure successful exploitation of the industrial ATS market, Solar Turbines has begun to identify candidates for the field demonstration of the industrial ATS. Solar Turbines must have a strategy that includes developing strategic alliances with organizations that can substantively assist Solar's entrance into electric utility markets in the U.S. and abroad. 


\section{CITED REFERENCES AND BIBLIOGRAPHY}

Primary sources cited in the text are listed with reference number in brackets [ ]. A working bibliography of sources consulted in preparing this report, but not directly cited, is also provided. 
B -10 


\section{List of Primary References}

[.1] "High Performance Steam Systems: Market Study," DOE, February 1992.

[2] "Public Power Directory," Public Power, January-February 1994.

[3] "Electricity Supply and Demand 1993 - 2002," NERC, June 1993.

[4] "Annual Energy Outlook," DOE/EIA, 1994.

[5] "Outlook for U.S. Power Markets," John Siegel, Bechtel Power Corp. 1993.

[6] "Technology: Triggering Structural Change in the Power Industry," by Kurt Yeager, EPRI, November 1993.

[7] "Impediments to New Natural Gas Markets, for INGAA Foundation by RCG/HBI, May 1992.

[8] "GRI Baseline Projection of U.S. Energy Supply and Demand," GRI, 1994.

[9] "Rural Electric Sourcebook," National Rural Electric Coopoerative Association, 1990.

[10] "Rewriting the Rules on Energy," Walker F. Nolan and Lynn H. LeMaster, Electric Perspectives, January/February 1993.

[11] "Future Power Supply," Newton A. Campbell and Kiah Harris, Public Power, March-April 1993.

[12] " Technical Assessment Guide (TAG): Electricity Supply," EPRI, 1993.

[13] "1992 Energy Technology Status Report," CEC, November 1992.

[14] AGA TERA Demand/Marketplace Model Output, AGA, December 1993.

[15] "Gas-Fired Powerplants," Steven Collins, Power, February 1993.

[16] Conference Papers, Power-Gen '93, November 17-19, 1993.

[17] "Petroleum Storage and Transportation," National Petroleum Council, 1989

[18] "Compressor Station Technologies: Option for the Next 20 Years," prepared for AGA, GRI, and the Pipeline Research Council, December 1993.

[19] "Cutting Compliance Costs: NOx Control at Pipeline Compressor Stations," GRI, Winter $1993 / 1994$. 
[20] "High Performance Steam Systems: Mechanical Drive Market Assessment," DOE, October 1991.

$\therefore$

[21] "Reliability of Natural Gas Cogeneration Systems," GRI, September 1992.

[22] "Independent Energy Producers: The New Electric Generating Sector," National Independent Energy Producers, September 1989.

[23] "Competing for Power: A Survey on Competitive Procurement Systems and Blueprint for the Future," National Independent Energy Producers, July 1991.

[24] "Meeting Electricity Needs in the 1990s," Edison Electric Institute, September 1991.

[25] "Clean Air Act Compliance and its Effect on Independent Power Producers," LG\&E Power Engineers and Constructors Inc., presented at Power-Gen Americas '93, November 17-19, 1993.

[26] "Inventory of Power Plants in the United States 1992," Energy Information Administration, U.S. Department of Energy, October 1993.

[27] "U.S. Electric Utility Generating Capacity is Aging," Dianne Moody, Public Power, JanuaryFebruary 1994.

[28] "Generating Availability Report 1988-1992," North American Electric Reliability Council, June 1993.

[29] "Advanced Generating Technologies: Motivation and Selection Process in Electric Utilities," Murty P. Bhavaraju, Proceedings of the IEEE, Vol. 81, No.3, March 1993.

[30] "Crossing the Trēshold," Elliot Roseman and Jean-Louis Poirier, Electric Perspectives, July/August 1993.

[31] "Independent Power: State of the Market," Marie Leone, Power, February 1994.

[32] "Strategic Planning in Turbulent Times," Anthony Walz, Electric Perspectives, January/February 1994.

[33] "Distributed Generation," Daniel Rastler, EPRI Journal, April/May 1992.

[34] "Integrated Resource Planning in the States: 1992 Sourcebook," Edison Electric Institute, 1992.

[35] "Electricity Futures; America's Economic Imperative," Edison Electric Institute, 1994. 


\section{Working Bibliography}

$\therefore$

"Annual Energy Outlook," DOE/EIA, 1994.

"Inventory of Power Installations, " DOE/EIA, 1993.

"On-Going Development of a Low NOx Combustor for Cogeneration Gas Turbines," CEC, March 1993.

"Cost Effective NOx Emissions Reduction for Cogeneration Gas Turbines," CEC, 1991.

"1992 Energy Technology Status Report," CEC, November 1992.

"Energy Technology Trends and Opportunities," CEC, July 1990.

"Energy Development Report," CEC, December 1992.

"Energy Impacts of Measures in the SCAQMD 1989 AQMP," CEC, 1990.

"1992 Electricity Report," CEC, 1992.

"California Energy Demand 1993-2011," CEC, 1993.

"International Market Evaluations: Cogeneration Prospects, " CEC, 1987.

"Evaluation and Costing of NOx Controls for Existing Utility Boilers in the NESCAUM Region," EPA/OAQPS, December 1992.

"Alternative Control Techniques Document -- NOx Emissions from Stationary Gas Turbines," EPA/OAQPS, January 1993.

"GRI Baseline Projection of U.S. Energy Supply and Demand," GRI, 1994.

"1994 Policy Implications of the GRI Baseline Projection of U.S. Energy Supply and Demand to 2010," GRI, 1994.

"The Long Term Trends in U.S. Gas Supply and Prices: 1993 Edition of the GRI Baseline Projection," GRI, March 1993.

"Reliability of Natural Gas Cogeneration Systems," GRI, September 1992.

"Impediments to New Natural Gas Markets, for INGAA Foundation by RCG/HBI, May 1992. 
"High Performance Steam Systems: Mechanical Drive Market Assessment," DOE, October 1991.

"High Performance Steam Systems: Market Study," DOE, February 1992.

"The Development of Non-Utility Power Generation in the United States," USAID, October 1990.

AGA TERA Demand/Marketplace Model Output, AGA, December 1993.

"Natural Gas and Steam Technologies: Applications Manual," AGA, Draft - undated.

"Technology: Triggering Structural Change in the Power Industry," by Kurt Yeager, EPRI, November 1993.

"Outlook for U.S. Power Markets," John Siegel, Bechtel Power Corp. 1993.

"Generating Availability Report," "Reliability Assessment," "Electricity Supply and Demand," Systems Disturbances," "Generating Unit Statistics," NERC, all are latest annual reports.

"1992 Resource Program: 10 Year Plan," Bonneville Power Administration (BPA), October 1992.

"Pacific Northwest Loads and Resources Study," BPA, December 1993.

"Reduction of NOx and SO2 Using Gas Rebuming, Sorbent Injection, and Integrated Technologies," Clean Coal Technology, September 1993.

"The Emerging Era of Low-Emission, High-Efficiency Gas Turbines," Diesel and Gas Turbine Worldwide, June 1992.

"High Performance Marine Propulsion Systems," Diesel and Gas Turbine Worldwide, March 1994.

"Clean Energy Solutions: Independent Power and the Environment," November 1993, Planning for Competition: IRP and the Independent Power Industry," July 1993, "Managing Externalities: Market Challenges and Solutions," The Reliability of Independent Power: Operating, System, Planning, Fuel and Financial," September 1991, " Energy for the Future: Working Papers 1-3," 1989-1991, National Independent Energy Producers.

"Petroleum Storage and Transportation" National Petroleum Council, 1989, 5 Volume Report. 
" Technical Assessment Guide (TAG): Electricity Supply," EPRI, 1993.

"Clean Air Act Compliance and its Affect on Independent Power Producers," Cecil D. Sterling and Paul R. Hunt, LG\&E Power Engineers and Constructors Inc., Presented at PowerGen Americas 1993, November 17-19, 1993.

"Regulatory and Economic Flexibility for NOx Control," Vincent M. Albanese, Nalco Fuel Tech, Presented at PowerGen Americas 1993, November 17-19, 1993.

"An Evaluation of Advanced Gas Turbine Cycles," Ashok D. Rao and Valerie J. Francuz, Fluor Daniel, Inc., Paul J. Bautista, GRI, Presented at PowerGen Americas 1993, November 17-19, 1993.

"Combustion Turbine Power Systems A Critical View of the Markets," Dale R. Simbeck, S. Vejtasa and Alan D. Karp, SFA Pacific, Presented at PowerGen Americas 1993, November 17-19, 1993.

Application of the High Efficiency GE LM6000 Aeroderivative Gas Turbine to Municipal Utilities and Small Industrial Facilities, Paul R. MacGregor and Chris M. Veitch, General Electric, Presented at PowerGen Americas 1993, November 17-19, 1993.

"Status Report: Alzeta's Sub-9 ppm NOx Radiant Cell Boiler Technology Operational," James A. Gotterba, Alzeta Corporation, Presented at PowerGen Americas 1993, November 17-19, 1993.

"Rural Electric Sourcebook," National Rural Electric Cooperative Association, 1990.

"Electricity Futures: -America's Economic Imperative," Edison Electric Institute, 1994.

"Meeting Electricity Needs in the 1990s," Science Concepts, Inc. for Edison Electric Institute, September 1991.

"Fuel Cell Technology in Electric Utility Planning," Arthur D. Little for Edison Electric Institute, May 1993.

"Twenty Key Trends Shaping the Electric Utility Industry, " Edison Electric Institute, April 1992.

"Integrated Resource Planning in the States: 1992 Sourcebook, " Edison Electric Institute, 1992.

"Meeting Electricity Needs in the 1990s," Edison Electric Institute, 1991.

"Fuel Cells Hold Promise for Electric Power Generation," Douglas Smith, Power Engineering, February 1994. 
"Retrofit Control Technology for Reducing NOx Emissions," Steven Kuehn, Power Engineering, February 1994.

$\therefore$

"Identifying Impacts of Energy Sources," R.L. Tenney and P.E. Neil, Power Engineering, February 1994.

"Electric Utility Response to the Clean Air Act Amendments, " Ian Torrens and Jeremy Platt, Power Engineering, January 1994.

"Fuel Cells Near Commercial Reality," Steven Kuehn, Power Engineering, May 1993.

"Externalities Bias Planning Against Fossil-Fired Generation," Robert Smock, Power Engineering, July 1992.

"Power Generators Prepare for New Base Load Plants," Robert Smock, Power Engineering April 1992.

"Future Power Supply," Newton A. Campbell and Kiah Harris, Public Power, March-April 1993.

"U.S. Electric Utility Generating Capacity is Aging," Diane Moody, Public Power, JanuaryFebruary 1994.

"Strategic Planning: The Major Chailenges Facing Public Power Systems, " Larry Hobart, APPA, delivered to Wisconsin Public Power Inc. System, December 9, 1993.

"Electric Power Market Perspective," Kurt J. Conger, American Public Power Association, September 30, 1993..

"Future Capacity Expansion of Natural Gas Pipelines and Storage in North America:

Executive Summary," INGAA Foundation, 1993.

"Distributed Generation," Daniel Rastler, EPRI Journal, April/May 1992.

"Investigation of Advanced Gas Turbine Cycles," EPRI TR-102441, July 1993.

"Its Time is Coming [Fuel Cell]," Bob Bruce, Public Power, March/April 1994.

"Rewriting the Rules on Energy," Walker F. Nolan and Lynn H. LeMaster, Electric Perspectives, January/February 1993.

"Molten Carbonate Fuel Cells as Distribuuted Generation Resources: Case Studies for the Los Angeles Department of Water and Power," M.M. El-Gasseir, EPRI TR-100680, May 1992. 
"Applications of Carbonate Fuel Cells to Electric Power Systems," EPRI TR-102931, September 1993.

"Evaluation of the Westinghouse Solid Oxide Fuel Cell Technology for Electric Utility Applications in Japan," EPRI TR-100713, May 1992.

"Carbonate Fuel Cells and Diesels as Distributed Generation Resources," EPRI TR-1021, October 1993.

Assessment of the Benefits of Distributed Fuel Cell Generators in the Service Areas of Cenral \& South West Services, Inc.," EPRI TR-102468.

"TAG: Technical Assessment Guide - Electricity Supply - 1989," EPRI P--6587-L Volume 1: Rev. 6, September 1989.

"TAG: Technical Assessment Guide - Fundamentals and Methods - Electricity Supply," EPRI P--6587-L Volume 3: Rev. 6, December 1991.

"Solid Futures in Fuel Cells," John Douglas, EPRI Journal, March 1994.

"Natural Gas as a Power Plant Fuel," Power, February 1994.

"Reducing NOx Emissions from Today's Powerplants," Jason Makansi, Power, May 1993.

"When Market Evolution Creates a Fatal Flaw in Gas Turbine Economics," Howard W. Holland and Ronald L. Scheirer, ASME Cogen-Turbo IGTI-Vol. 6, 1991.

"Gas-Fired Powerplants," Steven Collins, Power, February 1993.

"Oil Industry Outlook," Robert J. Beck, Penn Well Books, 1992.

"ACTs Set for Takeoff," EPRI Journal, October/November 1993.

"Retrofit NOx Controls for Utility Boilers," EPRI Report TR 102906, March 1993.

"Assessment of Electric Motor Technology: Present Status, Future Trends, and R\&D Needs," EPRI TR-101264, December 1992.

"Proceedings: Second International Conference on Compressed Air Energy Storage," EPRI TR-101770.

"Industrial Advanced Turbine Systems Market Characterization", CEC, October 1994.

"The Market Potential for SMES in Electric Utility Applications", ORNL, n/a. 


\section{THE RDC TEAM}

RDC, Inc., a small business corporation located in San Francisco, California, provides consulting services to government and commercial clients on the resource issues critical to the solution of complex and interrelated energy, technology, economic and environmental problems. The firm's clients are government agencies, industry, utilities, and developers in the U.S. and abroad. These services range from conducting technical studies of global issues to developing and implementing integral, practical solutions at local levels.

RDC, Inc. was well-qualified to perform the ATS market study on behalf of Solar Turbines Incorporated, since its staff members have conducted related studies on behalf of both government and commercial clients over the last 20 years, are knowledgeable of the DOE sponsored advanced gas turbine, and have demonstrated experience in advanced gas turbine markets. In addition, RDC, Inc. has developed exceptional analytical techniques which enable real-world comparative evaluations of competing technologies, allowing dynamic microsimulation of technology market development.

Dr. James H. Williams was the principal investigator in the industrial ATS market study. Since 1975, he has been principal investigator in roughly 300 assignments focusing on issues pertinent to technology assessments, RD\&D planning and evaluation, technology commercialization, and market strategy development and implementation. During the past 10 years, Dr. Williams has been assisting clients in developing and implementing R\&D and market strategies for products and services relevant to electric power generation, and energy use in the industrial, commercial, utility and transportation sectors. Since designing and evaluating many of the incentives contained in the National Energy Act of 1978 related to cogeneration development on behalf of ERDA, Dr. Williams has developed and implemented innovative complex methodologies designed to dynamically simulate market response to new technologies/products, new and modified laws/regulations and changes in energy market structure. His U.S. clients during this period represent all stakeholder segments in the fuel and energy technology markets and have included trade organizations (e.g., GRI, AGA), regulatory agencies (e.g., U.S. EPA, FERC), natural gas companies (e.g., Columbia Gas Distribution, Citizen's Gas \& Coke), electric utilities (e.g., SCE, SMUD, Oglethorpe), end users of fuels and energy technologies (e.g., Celanese, Sun Chemicals, Fiber Industries), and technology developers and vendors in the U.S. and abroad. He is Managing Director of RDC, Inc. He holds a Ph.D. in Physics from the University of Iowa, and a S.M. in Management from the Alfred P. Sloan School at M.I.T.

In addition to Dr. Williams, David Howarth was a key analyst and contributing author in the industrial ATS market study. He has five years of experience with ICF Incorporated and RDC, Inc. in conducting economic and resource policy analysis on environmental emissions, renewable energy and technology assessment. David holds a B.A. degree in Biology and Economics from Wesleyan University, and is currently pursuing a graduate degree in the Energy and Resources Group at the University of California, Berkeley. 


\section{APPENDIX C}

\section{ONSITE ENERGY REPORT}




\section{ADVANCED TURBINE SYSTEM \\ MARKET ASSESSMENT}

Summary Report

$$
\text { C-3 }
$$


C- 4 


\section{EXECUTIVE SUMMARY}

This report examines the U.S. power generation market for the Solar Turbines Incorporated (Solar) Industrial Advanced Turbine System (ATS), which once fully deployed will manifest itself as a portfolio of recuperated and simple cycle products spanning $1 \mathrm{MW}$ to $20 \mathrm{MW}$ in size. The resulting efficiency, environmental, reliability and cost attributes represent a major technology leap over state-of-the-art industrial gas turbines and positions the ATS to be a significant contributor to future U.S. generating capacity. The industrial ATS program is a partnership between Solar and the U.S. Department of Energy (DOE) to produce advanced turbine products that will provide national energy, environmental, export and employment benefits through its attractiveness to domestic and international industries.

High temperature alloys and ceramics, ultra low $\mathrm{NO}_{\mathrm{x}}$ combustion, advanced recuperator materials, a host of component efficiency improvements and "smart" controls comprise the core technology elements for the ATS product portfolio. Appropraite core technology will be applied across the spectrum of Solar's simple cycle gas turbine machines spanning $1 \mathrm{MW}$ to $20 \mathrm{MW}$.

\section{BACKGROUND}

A fundamental change is occurring in the U.S. electric power industry. Changes in generation technology and economics have created a competitive market for power supplies that successfully challenge the traditional view of an integrated (generation-transmission-distribution) utility that operates as a regulated monopoly. Non-utility generators (NUGs) have become an increasingly attractive economic alternative to large central station utility power plants. Today, many electric utilities are pursuing distributed generation technologies both as an investment opportunity and as an enhancement to the transmission and distribution grid. The days of "bigger is better," the fundamental tenet of a regulated monopoly, are over for the electric power industry.

Opening up competition for power supply was given a big push in 1978 with the passage of the Public Utilities Regulatory Policies Act (PURPA) that offered strong incentives to non-utility cogeneration and small power facilities, and mandated utility purchase of power from such facilities. More recently, the Clean Air Act Amendments of 1990 and the Energy Policy Act of 1992 have offered additional changes that will further promote the economic and environmental attractiveness of NUGs.

With the Federal Public Utility Holding Company Act (PUHCA) reform and the wholesale wheeling course largely set, retail wheeling is now moving to the top of some state energy regulatory agendas. In April of this year, California made the first move toward retail wheeling with the "Order Instituting Rulemaking and Order Instituting Investigation on the Commission's Proposed Policies Governing Restructuring California's Electric Services Industry and Reforming 
Regulation." In it, the California Public Utility Commission (PUC) proposed all-out state-wide retail wheeling, beginning with the largest industrial electric consumers in 1996 and ending with residential customers in 2002 . The debate and discussion process could last for several years. One thing is evident, future energy users will have more options than they have had in past, and considerable market and regulatory pressure will be exerted on utilities to become low cost (or best value) providers of electricity service.

A variety of forces have converged over the last two decades to transform the electric industry. The first challenge came from cogeneration, followed by the rise of independent power producers and the introduction of competitive bidding. Regulatory incentives have pushed acceptance of integrated resource planning (IRP), one result of which has been numerous demand-side management (DSM) initiatives. Environmental pressures and the societal advantages of efficiency weigh heavily in utility business decisions.

As a result, planning for energy delivery has become a high-stakes game. The ongoing obligation to serve consumers requires utilities to upgrade their infrastructure and to make investments that are costlier and riskier to the shareholder than before. As non-utility generators meet the majority of new power supply needs, utilities are for the first time spending more money on upgrading and expanding their transmission and distribution (T\&D) infrastructure than on capacity additions. Much of the cogeneration development thus far has been for large power plants where the primary objective was electricity sales into the wholesale power market. The retail displacement small power market languished as regulatory and market forces converged on deregulation of the bulk power market and as electric utilities fought hard to preserve their customer base.

The electric industry is now looking closely at the future role for small scale power technologies. Several factors are in play which are causing utilities to increase attention on small power generation:

\section{Customer Retention}

The growing trend of customer cogeneration and the likelihood for additional retail competition (wheeling) in the future have utilities examining customer retention strategies including rate restructuring, cost cutting and utility participation in customer cogeneration projects.

\section{New Revenue Opportunities}

As the electric industry progresses under deregulation, many utilities are looking more closely at unregulated opportunities to replace lost revenues from a shrinking rate base and from an eroding customer base. This interest goes beyond their existing franchise territories.

Distribution System Enhancements

Utilities are under ever increasing pressures to reduce the cost of service to be competitive in an "unregulated" world. More and more attention is being given to the transmission and 
distribution (T\&D) system, as it will likely represent the utility's most important strategic regulated asset. Small generation equipment is being recognized as an option for T\&D upgrades, which can be a cost effective way to defer or eliminate costly transformer and feeder investments. Distributed generation also offers supplemental generation capacity, adding further value to the utility "holdings."

Technology Advancements

Emerging small power technologies show potential for significant cost, environmental, efficiency and reliability improvements over currently available products. 
C- 8 


\section{APPENDIX C}

\section{REFERENCE MATERIALS}

$$
\text { C-9 }
$$


C-10 


\section{REFERENCE MATERIALS}

\section{ENERGY OUTLOOK}

1. 1994 POLICY IMPLICATIONS OF THE GRI BASELINE PROJECTION OF U.S. ENERGY SUPPLY AND DEMAND TO 2010 - Gas Research Institute

2. THE GRI ENERGY AND ECONOMICS STATISTICS REPORT - Analytic Research Corporation - January 1994

Prepared for: Gas Research Institute (GRI)

3. ANNUAL ENERGY OUTLOOK 1994 WITH PROJECTIONS TO 2010 - January 1994

DOE/EIA-0383(94), Distribution Category UC-950

Prepared by: Energy Information Administration, Office of Integrated Analysis and Forecasting, U.S. Department of Energy, Washington, DC 20585

4. FUTURE NATURAL GAS PRICES WILL BE COMPETITIVE - Power Engineering Magazine - March 1994

Prepared by: Robert W. Crawford, Director, Energy and Environmental Analysis, Inc.

5. ELECTRICITY SUPPLY \& DEMAND 1992-2001 - June 1992

Prepared by: North American Electric Reliability Council, 101 College Road East, Princeton, New Jersey, 08540-6601

6. ELECTRICITY SUPPLY \& DEMAND, 1993-2002 - June 1993

Prepared by: North American Electric Reliability Council, 101 College Road East, Princeton, New Jersey, 08540-6601

7. TECHNICAL ASSESSMENT GUIDE, Electricity Supply 1993, June 1993, Volume 1: Revision 7

Prepared by: Technology and Fuels Assessment Department, Electric Power Research Institute, Palo Alto, California

8. PRICING FOR GAS TURBINE PACKAGES, 1993-94

Prepared for: Gas Turbine World Handbook

9. ENERGY AND ENERGY MANAGEMENT MARKETS 1993-1996

Published by: Richard K. Miller \& Associates, Inc., 5880 Live Oak Parkway, Ste. 270, Norcross, GA, 30093

Prepared by: Richard K. Miller, C.E.M., Terri C. Walker, and Shuntay L. Gordon

10. ORDER INSTITUTING RULEMAKING AND ORDER INSTITUTING INVESTIGATION ON THE COMMISSION'S PROPOSED POLICIES 
GOVERNING RESTRUCTURING CALIFORNIA'S ELECTRIC SERVICES INDUSTRY AND REFORMING REGULATION.

Filed before the Public Utilities Commission of the State of California, April 20, 1994.

11. MAJOR INDUSTRIAL PLANT DATABASE (MIPD), Petroleum Information Corporation, 1991

12. COMMERCIAL BUILDINGS CHARACTERISTICS 1992 - APRIL 1994. DOE/EIA-0246(42); ENERGY INFORMATION ADMINISTRATION

13. ASSESSMENT OF ENERGY USE IN MULTI BUILDING FACILITIES, ENERGY INFORMATION ADMINISTRATION, DOE/EIA-0555(93)/2, AUGUST 1993.

14. THE CLIMATE CHANGE ACTION PLAN, OCTOBER 1993

Prepared by: President William J. Clinton and Vice President Albert Gore, Jr.

\section{DISTRIBUTED GENERATION}

15. DISTRIBUTED UTILITY VALUATION PROJECT - Monograph - July 1993

Final Report, August 1993, EPRI Report TR-102807, PG\&E Report 005-93.12

Prepared for: Electric Power Research Institute (EPRI)

National Renewable Energy Laboratory (NREL)

Pacific Gas \& Electric Company (PG\&E)

Program Managers: Stephen W. Chapel, EPRI; Lynn R. Coles, NREL; and Joseph J. Iannucci, PG\&E

Project Manager: Roger L. Pupp, Quantitative Solutions, 160 Sansome, Suite 400, San Francisco, CA 94104

16. REPOWERING POTENTIAL IN THE ELECTRICAL UTILITY SECTOR DRI/McGraw-Hill

Tropical Report, July 1993, Contract No. 5092-800-2374

Prepared for: Gas Research Institute

Prepared by: Lawrence Makovich and Julie Driscoll

GRI Project Manager: Paul D. Holtberg, Executive 'Economist, Strategic Planning \& Analysis Division

DRI/McGraw-Hill, 24 Hartwell Avenue, Lexington, MA 02173

17. ASSESSMENT OF THE BENEFITS OF DISTRIBUTED FUEL CELL GENERATORS IN THE SERVICE AREAS OF CENTRAL \& SOUTH WEST SERVICES, INC. - Rumla, Inc.

-Final Report, October 1993, TR-102468, Research Project 1677-25

Prepared for: Central \& Southwest Services, Inc., Post Office Box 660164, Dallas, Texas 75266-0164 and Electric Power Research Institute, 3412 Hillview Avenue, 
Palo Alto, California 94304

Prepared by: Rumla, Inc., 101 Ygnacio Plaza, Suite 203, Walnut Creek, California 94596 - M.M. El-Gasseir, Principal Investigator

EPRI Project Manager: D.M. Rastler

18. RESEARCH RESULTS AND UTILITY EXPERIENCE - DISTRIBUTED UTILITY VALUATION - Seminar Proceedings - March 15-16, 1994 - Hyatt Regency Baltimore

Host: Baltimore Gas \& Electric

Sponsors: Electric Power Research Institute, National Renewable Energy

Laboratory (U.S. DOE), Pacific Northwest Laboratory (U.S. DOE), Pacific Gas and Electric Company

19. CUSTOMER BACKUP GENERATION: DEMAND-SIDE

MANAGEMENT BENEFITS FOR UTILITIES AND CUSTOMERS, July 1991

Final Report, July 1991, EPRI CU-7316, Project 2950-5

Prepared for: Electric Power Research Institute

Prepared by: Energy International, Inc., Bellevue, Washington

EPRI Project Managers: W.J. LeBlanc, P. Hanser

20. THINKING SMALL: ONSITE POWER GENERATION MAY SOON BE BIG, Public Utilities Fortnightly, July 1, 1993.

Prepared by: Keith G. Davidson and Gerald W. Braun

\section{NON-UTMITY GENERATION}

21. IMPACT OF COGENERATION ON GAS USE IN THE INDUSTRIAL AND ELECTRIC UTILITY SECTORS - January 1986

GRI Contract No. 5085-800-1163

Prepared for: Gas Research Institute, Strategic Analysis and Energy Forecasting Division, Suite 730 North, 1331 Pennsylvania Avenue, N.W., Washington D.C. 20004-1703

Prepared by: B. Venkateshwara and S. Y. Salama, Energy and Environmental Analysis, Inc., 1655 North Fort Myer Drive, Arlington, Virginia 22209

22. RELIABILITY OF NATURAL GAS COGENERATION SYSTEMS - September 1992

Final Report, January 1990-September 1992, Contract No. 5089-293-1870

Prepared for: Gas Research Institute, 8600 West Byrn Mawr Avenue, Chicago, IL 60631

Prepared by: Harry W. Brown and F. Samuel Stuber

-ARINC Research Corporation, A Subsidiary of ARINC Incorporated, 2551 Riva Road, Annapolis, MD 21401 
23. CURRENT STATUS AND PROJECTED TRENDS IN INDUSTRIAL COGENERATION Draft Report, September 8, 1993

Prepared for: Gas Research Institute, 1331 Pennsylvania Avenue N.W., Suite 730

North, Washington, D.C. 20004-1703

Prepared by: Energy and Environmental Analysis, Inc., 1655 North Fort Myer

Drive, Suite 600, Arlington, Virginia 22209

24. OUTLOOK FOR NON-UTILITY POWER GENERATION, October 31-

November 3, 1993

Presented to: The International Conference on Natural Gas Technologies:

Energy Security, Environment and Economic Development

Presented by: Keith G. Davidson, Gas Research Institute, Kenneth G.

Darrow, Jr., Energy International, Inc.

25. CAPACITY AND GENERATION OF NON-UTILITY SOURCES OF ENERGY, November 1993

Prepared by: Edison Electric Institute Statistics Department, 701 Pennsylvania Avenue, NW, Washington, D.C., 20004-2690.

26. INDUSTRIAL AND COMMERCIAL COGENERATION, February 1983 Office of Technology Assessment Report, Library of Congress Catalog Card Number 83-600702

27. ASSESSMENT OF INDUSTRIAL COGENERATION MARKET DEVELOPMENT YEARS 1991-2005, January 1991

Prepared by: J. Williams, M. Chapman, M. Rollor, RCG/Hagler, Bailly, Inc., 370

L'Enfant Promenade, SW, Washington, D.C., 20024

Prepared for: Gas Research Institute

GRI Project Manager: Bruce A. Hedman, Industrial Utilities and Power

Generation Department

28. A COMPREHENSIVE ECONOMIC MODEL-BASED FORECAST FOR THE NUG MARKET, June 1993

Presented by: Paul MacGregor and James Oplinger, GE Industrial \& Power

Systems

Presented to: Cogeneration \& Independent Power Congress, June, 1993

\section{PIPELINE COMPRESSION}

29. COMPRESSOR STATION TECHNOLOGIES: OPTIONS FOR THE NEXT 20 YEARS

Final Report, December 1993, SRI Project 3184, A.G.A. Contract PR-215-9129

-Prepared for: Gas Research Institute and the Compressor Research Supervisory Committee of the Pipeline Research Committee at the American Gas Association Prepared by: Client Private SRI International, 333 Ravenswood Avenue, Menlo 
Park, CA 94025-3493

30. PREFERRED CHARACTERISTICS OF FUTURE COMPRESSION STATIONS: A PIPELINE INDUSTRY SURVEY

Interim Report, November 1992, SRI Project 3184, A.G.A. Contract PR-215-9129

Prepared for: Pipeline Research Committee American Gas Association, Arlington, VA

Prepared by: Client Private SRI International, 333 Ravenswood Avenue, Menlo Park, CA 94025-3493 


\section{BACKGROUND ON ONSITE ENERGY CORPORATION AND REPORT AUTHORS}

Onsite Energy Corporation ("Onsite") is a comprehensive energy efficiency services company ("ESCO") with over ten years experience in small power generation and energy efficiency. Onsite's services include consulting, feasibility studies, energy audits, design, construction management, project development, finance, and operations. Onsite's energy consulting services are targeted at utilities, product suppliers and government. The type of services provided include market assessments, product business strategies, public policy analysis, environmental impacts and feasibility studies related to integrated resource planning, energy utilization and small power production.

Onsite Energy's business focus is on the energy needs of institutional, commercial and industrial users. Onsite has a broad experience base including lighting, motors, energy management systems, HVAC systems, gas cooling, thermal energy storage, and power generation. Onsite's Customer list includes more than 100 projects in a variety of market sectors, including Hotels and Apartments; Education; Retail; Health Care and Hospitals; Commercial Office Buildings; Federal Government; Cities and Municipalities; County and State Agencies; and others.

Over the last four years, Onsite has served as Managing Partner for EUA/Onsite, L.P., a California Limited Partnership between Onsite and EUA Cogenex, a subsidiary of Eastern Utilities Associates. During this time, the general partners have served in the capacity of primary contractor and financier for over 850 energy efficiency projects.

Onsite has recently been selected for developing energy efficiency programs for the following utilities, both directly and through its EUA/Onsite financing partnership: Sacramento Municipal Utility District ("SMUD"), Tacoma Power \& Light, Puget Power and Light, PacifiCorp, Southern California Edison, and Nevada Power Company for a combined potential value in excess of $\$ 50$ million.

In February 1993, Onsite entered into an Agreement and Plan of Reorganization with Western Energy Management (AMEX:WEM) of Sacramento, California which resulted in the merger of the companies into the new Onsite Energy Corporation. On January 12, 1994, the Securities and Exchange Commission declared the registration statement in connection with the combination of Onsite and Western Energy Management effective; consummation of the Reorganization was approved by the shareholders of both companies on February 14, 1994, with trading on AMEX under the symbol ONS beginning February 16, 1994. Management of, and controlling interest in, the new corporation remains with the management of the former Onsite Energy private company.

Onsite's experience includes over thirty small power generation projects. As the developer, designer, owner and operator of many of these facilities, Onsite is a seasoned ESCO organization with a wealth of practical experience dealing with customer relationships, siting and environmental requirements, operational and maintenance needs, interfacing with the 
utility grid and project economics.

Through Onsite's experience with electric utility DSM programs, the company has developed a familiarity with integrated resource plans and the role for DSM in alleviating constraints in utility distribution grids.

Keith Davidson, Vice President, Project Development, Onsite Energy, is responsible for energy consulting, engineering services, power generation and DSM project development. Prior to joing Onsite, Keith had considerable experience in various management positions working with the gas industry to develop products and commercialization strategies for emerging gas markets including power generation, gas cooling and natural gas vehicles. While at GRI through January 1994, Keith has actively participated on the DOE/EPRI/GRI Gas Turbine Steering Committee, the Collaborative Advanced Gas Turbine (CAGT) Executive Committee, American Gas Turbine Manufacturers Association (AGTMA), American Gas Association (AGA) Power Generation Committee, and the Natural Gas Council-Electric Generation Task Force. He is a member of the American Society of Heating, Refrigeration and Air Conditioning Engineers (ASHRAE), and the American Cogeneration Association's (ACA) Board Executive Committee. Keith was named the Association of Energy Engineer's Cogeneration Professional of the Year in 1989 and has been inducted into AGA's Industrial and Commercial Hall of Flame.

Teresa See Bryson, Project Manager, Onsite Energy, has over 15 years experience in project management and engineering in various industries, including renewable energy, biomass and defense. In addition to being a participant at various energy symposia, Ms. Bryson has been the national level representative and spokesperosn at several international conferences, and organized national and regional exhibits and workshops on energy and the environmental issues. Prior to joining Onsite, Ms. Bryson held the positions of Project Director for the USAID Renewable Energy Development Project, and Chief of Energy Conservation and Renewable Energy Development for the National Energy Commission for the Republic of Panama, and recently held the position of Facilities Management Engineering Director for the U.S. Navy's Public Works Department in Holy Loch, Scotland. 